\title{
ESTIMATING DISCOUNT RATES ${ }^{\dagger}$
}

\section{Laurence Booth}

\section{SUMMARY}

Discount rates are essential to applied finance, especially in setting prices for regulated utilities and valuing the liabilities of insurance companies and defined benefit pension plans. This paper reviews the basic building blocks for estimating discount rates. It also examines market risk premiums, as well as what constitutes a benchmark fair or required rate of return, in the aftermath of the financial crisis and the U.S. Federal Reserve's bond-buying program. Some of the results are disconcerting. In Canada, utilities and pension regulators responded to the crash in different ways. Utilities regulators haven't passed on the full impact of low interest rates, so that consumers face higher prices than they should whereas pension regulators have done the opposite, and forced some contributors to pay more. In both cases this is opposite to the desired effect of monetary policy which is to stimulate aggregate demand. A comprehensive survey of global finance professionals carried out last year provides some clues as to where adjustments are needed. In the U.S., the average equity market required return was estimated at 8.0 per cent; Canada's is 7.40 per cent, due to the lower market risk premium and the lower risk-free rate. This paper adds a wealth of historic and survey data to conclude that the ideal base long-term interest rate used in risk premium models should be 4.0 per cent, producing an overall expected market return of 9-10.0 per cent. The same data indicate that allowed returns to utilities are currently too high, while the use of current bond yields in solvency valuations of pension plans and life insurers is unhelpful unless there is a realistic expectation that the plans will soon be terminated. 


\section{SECTION I}

Many terms in finance can be confusing when they are used to mean the same thing. This is particularly true for the term "discount rate". Conceptually, the discount rate is an individual's marginal rate of substitution between current and future wealth, that is, the slope of the individual's indifference curve when faced with investment decisions. As such, it is the minimum rate of return required by an individual to make an investment, so it is also called the required rate of return. If an investment offers a higher rate of return, the individual buys it, since it generates incremental or positive net present value, that is, the rate of return is higher than that required. In "equilibrium" when we aggregate across all individuals, this market required rate of return equals the expected rate of return on the market value of the investment. Since individuals in aggregate dislike delaying consumption and bearing risk, this required rate of return is positive and future values sell for less when sold today, that is, cash flows are discounted or reduced to their present value. Consequently, this required rate of return is also called a "discount rate". Finally, since what the market (aggregate of all individuals) requires is what the firm has to pay to raise equity capital, this discount rate is also the firm's cost of equity capital. ${ }^{1}$

Consequently in finance, the terms "minimum required rate of return", "discount rate", 2 "expected rate of return on an investment", "cost of equity capital" and the ubiquitous "opportunity cost" all mean essentially the same thing. It is the rate of return that ties together all the participants in the capital market, both those supplying capital (investors) and those demanding it (corporations and other individuals). Value is created for individuals, firms and society, when capital is correctly allocated to investments that exceed the market discount rate. This in turn has spawned a whole industry in performance measurement; to ensure that firms create shareholder and social value. ${ }^{3}$

Given its theoretical importance, it is hardly surprising that estimating discount rates is an important part of applied finance. In particular, it is absolutely critical in two areas, public utility regulation and pension and insurance valuation, as well as its obvious importance in almost all applied investment analysis where it is needed in conventional valuation. In public utility regulation, for example, Hydro One Transmission had regulated assets (rate base) in 2010 of $\$ 17.322$ billion so a $0.25 \%$ change in its allowed return on equity (ROE), which is a direct transformation of its cost of equity capital, cost consumers about $\$ 20$ million. However, of even more importance is its impact on pension and insurance valuation.

Halina von dem Hagen ${ }^{4}$ points out that actuarial liabilities represent approximately $\$ 200$ billion of Manulife's total liabilities. Since a large proportion of these liabilities tend to be very long term, even a very small change in the assumed discount rate causes a very significant change in their valuation. For example, assuming that the longest liability cash flows are supported by assets the value of which does not fluctuate in response to interest rate changes, a 10bps change in the discount rate applied to $\$ 50$ billion of reserves of 20-year duration would move liabilities, and hence earnings, by $\$ 1$ billion on a pretax basis.

\footnotetext{
1 Assumes zero frictions.

2 I have finessed risk at the moment but risk-adjusted discount rates are used when applied to investments differing in risk.

3 This glosses over issues involved with market imperfections, such as transaction costs, income taxes, externalities, public goods, information asymmetries etc., which may cause social discount rates to diverge from private discount rates.

4 "Getting the discount rate right." Presentation to the University of Calgary Financial Regulation Roundtable, June 25, 2014
} 
Pension valuations are similarly sensitive to choices of discount rates. In valuing their liabilities pension funds incorporate the cost of equity capital and long term interest rates directly into the assumed investment return for a going concern valuation. However, for a solvency and wind-up valuation purposes, the discount rate is generally prescribed to be that on a long Canada bond either with or without inflation indexation of benefits. This is done under the assumption that the liabilities can be replaced with life annuities from an insurance company, and so need to directly reflect current market interest rates.

It is thus very important that the discount rate is specified correctly in order to set public utility rates, pension contributions, and life insurance rates. Yet, since the onset of the financial crisis, considerable controversy has emerged as to whether the old rules/procedures have remained constant or changed, that is, whether or not we now have a "new normal."

For example, prior to 2008 in public utility regulation, there was a general consensus that the allowed ROE to utility common shareholders ${ }^{5}$ could be determined in a formulaic way based on changes in forecast long Canada bond yields. Most Canadian regulators based the allowed ROE to the utilities they regulated on a formula introduced in 1994 by the National Energy Board. ${ }^{6}$ However, starting with the NEB in 2009, these formulae have been dropped or substantially changed, and even those that reinstated them in 2011 have mostly reverted to a fixed rate of return.?

Similarly, Canadian pension funds have been hit with downgraded expectations as to their future return on assets for their going concern valuations, as well as reduced discount rates in their solvency valuations. These lower discount rates have increased the value of their liabilities, thereby exacerbating unfunded liabilities in defined benefit pension plans. Some have even proposed that the "new normal" of low government interest rates has dramatically increased the "cost" of public sector defined benefit pensions ${ }^{8}$ and whether they remain fair. In some cases, this has caused contribution rates to increase and forced sponsors to make special payments to rectify increased solvency deficits.

At the same time, annual surveys of market participants have indicated little to no change in market risk premium estimates, so there is little to indicate that professional investment advisors have significantly changed their view as to how to determine appropriate discount rates.

This paper looks at the empirical evidence of the market risk premium in the U.S. and Canada and what constitutes a benchmark fair or required rate of return. Section II will briefly review why public utility regulators "need" this information and why it is so important for a private pension plan. Section III will provide historic estimates of market rates of return and the basis for a reasonable expected rate of return. Sections IV-VII looks to some corroborating evidence for the U.S. and expectational data and the argument in favour of a "new normal." Section VIII adds some conclusions.

5 The allowed ROE inn utility regulation is essentially the cost of equity plus a small spread ( $0.50 \%$ usually) to reflect the fact it is applied to book instead of market values.

6 This is the RH-2-94 formula which changed the allowed return on equity (ROE) by 75 per cent of the change in the forecast long Canada bond yield. Similar formulae were then introduced by the Ontario Energy Board, the BC Utilities Commission, the Alberta Utilities Commission, the Board of Commissioners of Newfoundland and Labrador and the Regie de l'Energie du Quebec.

7 This is the Regie and Board of Commissioners of Newfoundland and Labrador. For 2013 the BCUC has reinstated a formulaic fair return.

8 Robson B and A. Laurin, "Supersized superannuation, the startling fair value costs of federal government pensions," Toronto CD Howe Institute, 2009 uses the return on the Government of Canada real return bond as the discount rate for Government of Canada pensions. The yield on the long term real return bond (CANSIM series V122544) has ranged since the time of issue in 1991 from 5.03 per cent to 0.33 per cent. If this had been used to set contribution rates it would have injected huge volatility into the pension plan. 


\section{SECTION II THE IMPACT OF REGULATION}

Regulated utilities operate with large, immobile fixed costs, negligible marginal costs and "transmit" a service that cannot be effectively arbitraged. The cost structure means that average costs decline with output to a scale that makes entry difficult for a potential competitor, since an incumbent can lower prices to deter entry by imposing significant losses. In the extreme case an incumbent can simply cross subsidise from other operations to make it uneconomic for any entry; the mere threat of this acts as a deterrent. The incumbent can then charge monopolistic prices that cause economic inefficiency. As a result, these firms are regulated to mimic the pricing behaviour of competitive firms, rather than being left to act like monopolists.

This basic economic description is illustrated below with the cost structure of Hydro One, which is the largest electricity transmission company in Ontario.

\begin{tabular}{|lc|}
\hline & \$millions $\mathbf{2 0 1 0}$ \\
\hline Operation, maintenance and admin & 1,078 \\
Depreciation and amortisation & 583 \\
Financing charges (interest) & 342 \\
Payments in lieu of taxes' & 56 \\
Net Income & 591 \\
Total Assets & 17,322 \\
\hline
\end{tabular}

\section{Hydro One is provincially owned and does not pay corporate income taxes}

What is important is that Hydro One's financial costs, that is depreciation, financing charges, income taxes and net income, amounted to $\$ 1,542$ million and exceeded operating costs by a significant margin.

Due to the capital intensive nature of Hydro One's operations, and like most utilities, large amounts of equity capital are contributed early and "locked in" creating a subsequent requirement to ensure that the shareholders are treated fairly and the financial costs generate fair and reasonable rates. ${ }^{9}$ The financial costs include the costs of debt and equity, which in turn, includes preferred and common shares. In the case of debt and preferred shares, the payment to the investor is fixed at the time of issue. As a result, the embedded cost is passed on to the ratepayer. The major problem is the cost of common equity financing, which does not have an explicit, easily calculated cost. Here the benchmark decision is the BC Electric decision, where the Supreme Court of Canada adopted Mr. Justice Lamont's definition of a fair rate of return as enunciated in the Northwestern Utilities Limited v. City of Edmonton ([1929] S.C.R. 186) decision that:

"By a fair return is meant that the company will be allowed as large a return on the capital invested in its enterprise (which will be net to the company) as it would receive if it were investing the same amount in other securities possessing an attractiveness stability and certainty to that of the company's enterprise.”

Mr. Justice Lamont's definition embodies what a financial economist would call a "risk-adjusted rate of return," an "opportunity cost," a "cost of equity capital," or a "discount rate."

9 Most Canadian utilities are regulated under acts that stipulate that rates be "fair and reasonable" or "fair and just." 
This definition has constantly been reaffirmed by utility regulators in Canada. For example, the Alberta Energy and Utilities Board stated (Generic Cost of Capital Decision U-200452, page 24):

"The Board considers that the application of a market required return (i.e. required earnings on market value) to a book value rate base is appropriate in the context of regulated utilities."

The upshot is the utility regulators frequently have rate hearings during which the fair rate of return to the common shareholder (ROE) is the most contested item. This occurs because it is the most difficult item to estimate objectively and also because it directly affects the shareholders, whereas most other costs are passed on.

For 2013, the fair ROE set by different Canadian regulators, mainly for benchmark or typical utilities, are as follows:

\begin{tabular}{|l|l|}
\hline Ontario Energy Board: & 9.36 per cent \\
Alberta Utilities Commission: & 8.75 per cent \\
BC Utilities Commission: & 8.75 per cent \\
Board of Commissioners of Newfoundland and Labrador & 8.80 per cent \\
Regie de l'Energie du Quebec: & 8.90 per cent $^{2}$ \\
Nova Scotia Utilities and Review Board: & 9.0 per cent $^{3}$ \\
\hline
\end{tabular}

1. Current rate; placeholder for hearing in June 2014.

2. Gaz Metro decision, D2011-182

3. Maritime Link Decision 2013-154

Apart from the Ontario Energy Board's fair ROE, these allowed ROEs are at or under 9.0 per cent. Note these are the allowed rates of return on the book value of shareholder's equity. In most cases, regulators allow these ROEs to exceed their estimate of the discount rate or equity cost by 0.50 per cent, or in the case of the Regie, by 0.30 per cent. So these recent regulatory decisions are consistent with a market opportunity cost for investing in stable utility companies of 8.25-8.50 per cent.

In contrast, Schedule 1 provides a graph of the annual ROE allowed under the National Energy Board's ROE formula, again the opportunity cost would be about 0.50 per cent less than this allowed ROE. The allowed ROE starts out for 1995 when the NEB used a forecast 9.25 per cent long Canada bond yield and an "all-in" 3.0 per cent utility risk premium for a fair ROE of 12.25 per cent. Thereafter, the ROE changed by 75 per cent of the change in the forecast long Canada bond yield for the future test year. ${ }^{10}$ For 2013, the allowed ROE from the NEB formula was 7.23 per cent, significantly below that allowed by most utility regulators of 8.75-9.0 per cent indicating the significant rebasing that has occurred since the financial crisis. The drop in the allowed NEB ROE was driven by the collapse in the long Canada bond yield to a forecast level for 2013 of 2.59 per cent. The NEB had decided that the fair ROE declined by 75 per cent of the decline in long Canada bond yields, so there was a built in inverse relationship between the discount rate and the long Canada bond yield. However, once bond yields dropped to very low real yields, the NEB abandoned its formulaic approach to setting the fair return. The basic message from recent regulatory decisions is that the discount rate has not perfectly followed the yield on the long Government of Canada bond downward. ${ }^{11}$

\footnotetext{
${ }^{10}$ Utilities are regulated on a forward test year basis so most use a forecast long Canada bond yield based on the Consensus Economics forecast of the yield on the ten year bond, plus a spread to convert it to a forecast for the yield on the 30 year benchmark bond.

${ }^{11}$ Note that utility rate hearings are a gold mine for academics, since there is an enormous amount of information presented by financial experts on the fair rate of return.
} 
In contrast to utility regulators, actuaries incorporate these low bond yields directly into their wind-up or solvency valuations of defined benefit pension liabilities. ${ }^{12}$ Under Ontario government regulations, any solvency deficit in a defined benefit plan must be amortised with special payments to address the deficit. ${ }^{13}$ However, the huge increase in the value of defined benefit pension liabilities caused by very low interest rates has forced the Ontario government first in 2009 and again in 2012 to provide extra solvency "relief" for private sector defined benefit pension plans. ${ }^{14}$ These measures have allowed plan sponsors to consolidate special payments and phase them in first over a five- and now a ten-year period. ${ }^{15}$ However, the ultra-low long-term interest rates pushed the median solvency ratio for defined benefit pension plans in Ontario down to $74 \%$ in December 2012, indicating a significant deterioration. Though that median solvency rate for Ontario pensions has rebounded (to 94\%) one year later, the debate continues. That debate also extends beyond pension plans. Based on internal analysis by companies such as Manulife, the life insurance industry also is retaining significantly more capital for solvency purposes due to the impact of the low interest rate environment on the valuation of actuarial liabilities and regulatory capital requirements.

What is striking is the disparate ways in which regulators have responded to the post financial crisis "new normal." Utility regulators have dispensed with well used and accepted formulae for determining the allowed ROE, whereas the Ontario Government has mainly lengthened the period over which special payments must be made to address pension solvency deficits, without altering the assumption that low current interest rates should be incorporated. ${ }^{16}$ Put another way, consumers are paying higher rates for using utility services like gas and electricity because their regulators have not passed through the full impact of low interest rates, while defined benefit pension plan sponsors and contributors are paying more because their regulators have! ${ }^{17}$ All of this is occurring at a time when consumers are getting lower returns on their GICs and standard savings products. Given the differing behaviour of regulators, it is important to understand the historic record and what if anything has changed.

\section{SECTION III THE HISTORIC RECORD OF EARNED RETURNS}

Remember that in equilibrium, the discount rate, or required rate of return, is equal to the expected rate of return. We can therefore observe the discount rate if we can observe expected rates of return. Further, if actual rates of return are simply the expected rate of return plus a random error term, or

$$
R_{t}=E\left(R_{t}\right)+\varepsilon_{t}
$$

\footnotetext{
${ }^{12}$ Going concern valuations can use a long run rate of return on plan assets but must be 3 per cent higher than the CPI inflation rate assumption (CRA 72-13R8). Solvency and wind-up valuations in Ontario are determined using Ontario Government interest rate assumptions under the assumption the liabilities would be purchased by an insurance company.

13 Pension Benefits Act.

${ }^{14}$ See 2012 Report on the Funding of Defined Benefit Pension plans in Ontario, Financial Service Commission of Ontario, August 2013.

15 These regulations are premised on the idea that these liabilities can be settled by selling them to an insurance company. For some they may be, but not for the larger plans like Ontario Teachers Pension Plan at well over $\$ 100$ billion.

${ }^{16}$ This reflects the assumption that the liabilities can be taken over by an insurance company, which in many cases is doubtful.

${ }^{17}$ Note in order to get special funding relief, Ontario requires that pension plans move to a 50:50 funding basis. At the University of Toronto this has caused an increase in faculty contribution rates in an employer sponsored plan even though the plan's deficit is a combination of abysmal plan performance over which the Faculty has no control and the impact of an 18 year contribution holiday taken by the University when results were "good."
} 
Then, if we assume some constancy so we can ignore the time subscript, we can estimate the expected rate of return simply by averaging over long time periods. For individual stocks, the constancy assumption is highly unlikely to be satisfied, but for the overall stock market, it is less problematic. So, looking to the historic data on the overall stock market return provides an idea of the overall market discount rate. This is important since from most financial theory, the market return is the anchor to which all other discount rates are attached.

For the historic record, I rely on the Canadian Institute of Actuaries' annual Report on Canadian Economic Statistics ${ }^{18}$ and the Morningstar Ibbotson's Stocks, Bonds, Bill and Inflation Yearbook for the U.S. It is imperative though to bear in mind important structural changes that have occurred across time. For Canada, we have good data on long-term bonds going back to 1936, since that is the founding date of the Bank of Canada. However, it was not until the structural changes in 1953-4 that a true money market emerged in Canada and there was an active secondary market. Similarly for equities, we have data back to 1922. However the latter date is a bit spotty. The TSX has pushed the TSX300 (now Composite) back to 1956 and the Canadian Institute of Actuaries has created data going back further by using the TSE Corporates series and a composite series from Urquhart and Buckley. ${ }^{19}$ Because of the deficiencies of the Canadian data, it is useful to also look at the U.S. data as a point of comparison.

The CIA and Ibbotson SBBI data that I use are annual data, i.e., provide the total annual rate of return, including reinvested dividends. The choice of intervalling period turns out to be quite important as I will discuss later, but most utilities are regulated on an annual forward test year basis, while most corporate decisions involve discounting annual cash flows, so annual rates of return seem appropriate. However, defining rates of return involves some subtle problems.

Consider, for example, a stock that goes from $\$ 50$ to $\$ 100$, its rate of return over that period is 100 per cent. However, if it subsequently drops back to $\$ 50$, then in this second period its rate of return is -50 per cent. The average of these two rates of return, referred to as the arithmetic mean return $(A M)^{20}$, is +25 per cent where the problem is that you are back to the same $\$ 50$ you started with. The compound or geometric return $(\mathrm{GM})^{21}$ is the rate of return you get if you ask what rate of return generates $\$ 50$ if you started with $\$ 50$ over two periods. Here the answer is clearly 0 per cent. The difference between the two depends on the amount of volatility between the two periods and what is itself defined as the "period." If there were no intervening uncertainty, or the period had been defined as one single period, then the AM would also have been 0 per cent.

The basic difference between the AM and GM is how to deal with the intervening uncertainty, which is the intervalling problem. If the logarithm of one plus the rate of return is approximately normal, this difference between the AM and GM is half the variance of the rate of return. ${ }^{22}$ As a result, the more intervening uncertainty, the greater the difference between the arithmetic and geometric, or compound, rate of return. By calculating total rates of return over very long periods, we are essentially asking: how fast would wealth grow if invested in different asset classes? One final standard estimation procedure is

\footnotetext{
18 The latest report is May 2013. The Ibbotson SBBI is for 1926-2012.

${ }^{19}$ However, dividend data is not available until after 1933, before then the U.S. SP500 dividend yield series is used plus a yield correction based on subsequent differences.

20 The AM is defined as $\sum_{t=1}^{T} \frac{\left(1+r_{t}\right)}{T}-1$

${ }^{21}$ The GM is defined as $\prod_{t=1}^{T}\left(1+r_{t}\right)^{1 / T}-1$

22 This is the lognormal distribution where the logarithm of $1+\mathrm{r}$ is defined as the continuously compounded rate of return. The average continuously compounded rate of return is the geometric rate of return. See John Hull, Options, Futures and other Derivatives, Prentice Hall for a fuller discussion.
} 
to use ordinary least squares (OLS) regression to get the best linear unbiased estimator of the AM return by minimising the variance around the estimate. These are the three estimates of the rate of return from the major Canadian asset classes in Schedule 2.

Note the standard deviations of the annual rates of return are what we would expect: 18.34 per cent for equities indicates the riskiest asset class; 8.82 per cent for bonds ${ }^{23}$ the second riskiest and finally 4.20 per cent for 91-day Treasury Bills. If we take half the variance of the equities at 1.71 per cent, this is approximately the difference between the AM return of 11.40 per cent and the GM return of 9.77 per cent. Interestingly, the OLS estimate for the equity rate of return is 10.34 per cent or mid-way between the $\mathrm{AM}$ and GM estimates.

The historic data in Table 1 provides the basic ammunition to bound the estimate for the overall market required rate of return. How one interprets the historic data depends on how one interprets "stability". If you assume that the economy "repeats itself" in some form over long periods of time, since people are basically the same, while we have experienced a full range of natural, political and economic scenarios over the last 90 years, then you can arrive at several different interpretations:

The first is that the nominal rate of return is a random walk, which is equation (1) without the time subscripts. As such, the annual nominal rate of return is between the two OLS and AM estimates or 10.34-11.40 per cent.

The second is that the real rate of return is a random walk, which is equation (1) where R is defined as the real rate of return, so we should look at the final row for the excess return of equities over inflation for our real return estimate. On this basis, since inflation averaged about 3.0 per cent, we have a real return estimate of 6.53 per cent- 8.40 per cent based on the OLS and AM estimates.

The third is that the market risk premium is a random walk, so we should look at the second to last row in Table 1. On this basis, we have a market risk premium estimate of 4.37-4.97 per cent based on the OLS and AM estimates.

For the last two, a forward-looking estimate of the equity market return can then be obtained by combining these values with the forecast inflation rate and current long-term government bond yield. With a current long (30-year) Canada bond yield forecast of 3.40 per cent, this implies a forward estimate of the market expected rate of return of 7.77 per cent- 8.37 per cent, significantly lower than the historic average nominal return due to the lower current long Canada bond yield. With a current 2.0 per cent inflation forecast based on the Bank of Canada's operating range for core inflation, we would have a forward estimate of the market expected rate of return of 8.53 per cent- 10.40 per cent or again 1.0 per cent less than the historic nominal return due to the lower forecast inflation. Given the standard error of the equity return estimate of 1.95 per cent, none of these estimates can be ruled out as impossible.

Note that all these forward estimates are for the arithmetic mean or one-year-ahead rate of return. They are appropriate for a Monte Carlo simulation, where we sample from a distribution with these values for the arithmetic mean and standard deviation. For long run rates of return, we can either convert these to continuously compounded rates of return $(\operatorname{Ln}(1+\mathrm{r}))$ or use the geometric rate of return. If the distribution is exactly lognormal, these would produce the same forecast.

However, given the range of possible values for the expected AM return, it is important to look to other areas to narrow down the possible range for the market discount rate.

${ }^{23}$ Note these are one year holding periods so long term $\mathrm{G}$ of $\mathrm{C}$ bonds are risky if only held for one year. 


\section{SECTION IV U.S. DATA}

Schedule 3 presents the same data as Schedule 2 except for the period 1926-2013 for both the U.S. and Canada. Note that, for Canada, omitting two years of strong equity market data from the "roaring twenties" causes the equity market risk premium to drop by 0.20 per cent. This confirms how difficult it is to place sole reliance on historic data, when the equity return is so variable. However, of more importance is the broad similarity of the U.S. and Canadian results. Overall, the excess equity return over that in the bond market, or the estimate of the risk premium, in the U.S. was higher than that in Canada. But it is important to look at the reasons for the difference which is in Schedule 4.

For the AM returns, the estimate of the equity market risk premium was 1.47 per cent higher in the U.S. at 6.24 per cent than that in Canada at 4.77 per cent. However, this is split between an equity market difference of 0.84 per cent and a bond market difference of 0.63 per cent. The U.S. had both higher equity market returns and lower bond market returns resulting in a higher estimate of the equity market risk premium. If we look at the compound (GM) returns, these differences are less with a 1.19 per cent difference in the equity market risk premium split between a 0.52 per cent difference in equity market returns and a 0.67 per cent difference in bond market returns. For both the equity and market estimates, the higher volatility of U.S. returns causes a bigger drop from the AM to the GM compound return estimate of the equity market risk premium.

For a forward estimate we have to assess whether these differences are likely to persist. For the equity market, we can plausibly judge that the removal of many of the restrictions applied to both in and outward bound investment is likely to erase the $0.52-0.84$ per cent difference between the equity market returns by both lowering U.S. returns and increasing Canadian returns. ${ }^{24}$ For bond markets, we have to remember that we do not have to rely on argument, we can look directly at bond yields since at issue these are normally the market's required rate of return. ${ }^{25}$

In Schedule 5 is a graph of long-term government bond yields in the U.S. (GS20) and Canada (V122501) since 1994. In the mid 1990's, long-term bond yields were demonstrably higher in Canada than the U.S., as they had historically been, as the U.S. was a capital exporter and Canada an importer. This was exacerbated by huge fiscal deficits at the Federal level, which hit almost 10 per cent of GDP. However, by 1997, the Federal Government of Canada had removed its huge fiscal deficit and the supply of government debt in Canada began to decline relative to GDP. This caused Canadian government yields to decline to those of the U.S., and since the mid-2000's, generally, Canadian long-term government bond yields have been lower than those in the U.S.. Currently, long-term Canadian government bonds are about 0.60 per cent lower than their counterparts in the U.S.

A further factor is that the Government of Canada remains a AAA-rated borrower, whereas even the U.S. has been downgraded to AA+ by Standard and Poors. Schedule 6 displays the currency composition of foreign exchange reserves held by the major countries as reported to the IMF. What is notable is that in 2012Q3, there were insufficient reserve holdings of Canadian dollar debt to break them out as a separate category. However, starting in 2012Q4, the holdings of Canadian dollars became significant and since then, they have grown to $\$ 112$ billion. To put this in perspective, the total value of Treasury Bills outstanding (outside the Bank of Canada) is $\$ 150$ billion with about another $\$ 400$ billion of bonds. So

\footnotetext{
${ }^{24}$ As markets integrate equilibrium returns are lowered marginally due to diversification gains. Historically Canadian tax preferred investments have been restricted, while tax preferences still steer taxable investors to Canadian markets. See Cohn and Pringle (1973) and Booth (1987)

${ }^{25}$ Note these are required rates of return over the time to maturity of the bond, not the expected return over any shorter time period, such as a year, as this depends on the term structure of interest rates or the shape of the yield curve.
} 
adding this type of demand, amounting to about 20 per cent of the total stock, is a significant change. Of course, as more people buy Canadian bonds, their prices increase and their yields fall.

I would, therefore, judge the Canadian market risk premium to be higher than the historic estimate of about 4.77 per cent and feel comfortable with a range of 5.0-6.0 per cent over "normal" long-term government bond yields.

\section{SECTION V EXPECTATIONAL DATA}

Since the discount rate is, by definition, the investor's required rate of return, we can "estimate" it simply by asking a broad sample of people what their expectations are. This is what Pablo Fernandez and his colleagues at IESE business school in Spain have been doing each year since 2004. At the height of the recent financial crisis, Professor Fernandez ${ }^{26}$ surveyed finance professors around the world to find out what they used for the market risk premium. A key result is his Table 2 reproduced in Schedule 7. The table confirms the historic data that the U.S. market risk premium has averaged about 1.0 per cent more than in Canada. Interestingly, the median or middle person in the U.S. (and Australia) thought that in 2008, the market risk premium was 6.0 per cent, in Europe 5.0 per cent, in the UK 5.0 per cent and in Canada 5.1 per cent.

The second table from Fernandez in Schedule 7 indicates the full range of estimates for Canada. Most Canadian finance faculty in 2008 thought the market risk premium was either 5.0 per cent or 6.0 per cent. There were a few down at 2 per cent or 3 per cent and even two people up at 8.0 per cent. However, what is clear is that the market risk premium estimates judged to be reasonable by most finance faculty in 2008 are essentially the historic estimates.

Professor Fernandez with his colleagues followed up this survey with further surveys in 2009, 2010, 2011, 2012 and 2013, and extended the responses to include financial analysts and financial executives within non-financial companies, as well as professors of finance. The 2013 survey was answered by 7,012 respondents out of about 21,500 emails sent out, where 775 did not answer the survey. The 2,394 U.S. responses indicated an average market risk premium estimate of 5.7 per cent and a median of 5.5 per cent. For Canada, the 110 responses indicated a lower market risk premium with an average of 5.4 per cent and a median of 5.3 per cent. The maximum estimate of the market risk premium by the Canadian respondents was 12.0 per cent, the minimum 3.0 per cent.

Professor Fernandez also reports the trend over time in the estimate of the market risk premium for the U.S., where the survey received the most responses, which is as follows:

\begin{tabular}{|cccccc|}
\hline $\mathbf{2 0 0 8}$ & $\mathbf{2 0 0 9}$ & $\mathbf{2 0 1 0}$ & $\mathbf{2 0 1 1}$ & $\mathbf{2 0 1 2}$ & $\mathbf{2 0 1 3}$ \\
\hline $6.3 \%$ & $6.4 \%$ & $6.0 \%$ & $5.50 \%$ & $5.50 \%$ & $5.70 \%$ \\
\hline
\end{tabular}

Consistent with the prior table, in 2008, the average estimate of the U.S. market risk premium was 6.3 per cent. This increased marginally in 2009 to 6.4 per cent, but has subsequently dropped to 6.0 per cent, then 5.5 per cent and is now slightly higher at 5.7 per cent, probably for reasons I will come to. However, the data show no sign of any significant heightened market risk premium due to the aftermath of the

\footnotetext{
${ }^{26}$ Pablo Fernandez, "Market risk premium used in 2008 by professors: a survey with 1,400 answers," IESE working paper, April 2009.
} 
financial crisis. In fact, the U.S. market risk premium seems to have dropped quite significantly since before 2008 when markets were buoyant.

Of importance is that, although survey results are often criticized as largely a reporting back the historic data that was (is) in their textbooks, what is clear is that the trend in the average U.S. results does not indicate any increase in the market risk premium. That is, even if you believe the average level from the survey respondents is wrong, it is difficult to believe that the trend over time exhibits any bias.

One feature of the 2013 survey results is that Fernandez et al also surveyed the use of the risk-free rate in estimating the required rate of return. Textbooks normally use a Treasury Bill yield rather than the long-term government bond yield. However, the T. Bill yield only measures the fair rate of return over a very short time period and is of little value for long-term investment decisions ${ }^{27}$ For the U.S., the riskfree rate used averaged 2.40 per cent, while that for Canada was 2.0 per cent. This is broadly consistent with the yields on 20-year government debt at the time of the survey. (May-June 2013). Fernandez then directly estimated the overall required return on the U.S. and Canadian equity markets, which is simply the sum of the market risk premium and the risk-free rate. For the U.S., the average equity market required return was estimated at 8.0 per cent, while that in Canada 7.40 per cent or 0.60 per cent lower due to both the lower market risk premium and the lower risk-free rate.

The upshot of the Fernandez expectational data is that, while the market risk premium is within what I would regard as a reasonable range, it is applied to a currently low long-term government bond yield. This results in historically low expected equity market rates of return.

\section{SECTION VI CORPORATE EARNED RATES OF RETURN}

Ultimately, stock market returns are driven by the returns earned by companies, that is, an economy with very unprofitable companies is not going to deliver stellar equity market returns and vice versa. In 1925, John Maynard Keynes pointed out ${ }^{28}$ that there were two sources of returns from investing in the stock market. The first is called the investment return which Keynes defined as "forecasting the prospective yield of an asset over its entire life." ${ }^{29}$ In modern terminology, this would be the internal rate of return on the firm's cash flows, or an approximate average return on equity. The second component he called the speculative return, which involved forecasting the psychology of the market and what Keynes referred to as the change in the basis of valuation. In modern terminology, this would be a change in the price-earnings ratio. Keynes discussed this speculative return as being generated by the "state of confidence" and "animal spirits" but he also pointed out it is affected by the level of interest rates. ${ }^{30}$

Keynes' point would be that a firm may earn 10 per cent, but if the valuation of that firm changes by 10 per cent, then the investor would earn both a speculative return as well as an investment return. This total return is then what we look at when we look at the returns over long periods of time on the TSX Composite or the SP500. However, in aggregate, the change in the basis of valuation cannot go on forever. We cannot continue to have a state of high confidence any more than interest rates can continue to increase or decrease; both of them will tend to revert back to some long run average due to actions

\footnotetext{
${ }^{27}$ It is also highly sensitive to short term monetary policy.

${ }^{28}$ Quoted in John Bogle, The Lessons of History, September 12, 2011, John Maynard Keynes, 1925, Review of Common Stocks as Long Term Investments, Edgar Lawrence Smith

29 This definition comes from chapter 12 of the General Theory of Employment Interest and Money, Macmillan London, 1936

${ }^{30}$ Page 149 of the General Theory
} 
by both investors and governments. However, professional investors, according to Keynes, are mainly concerned with speculative returns or forecasting the change in the basis of valuation six months out. In contrast, buy and hold or fundamental investors are mainly concerned with the investment return: finding good companies and holding them regardless.

Warren Buffet is probably the most successful fundamental investor of the last fifty years. He repeated Keynes' argument by stating: ${ }^{31}$

"The most the owners in aggregate can earn between now and judgment day is what their businesses in aggregate earn. (italics in original) True by buying and selling that is clever or lucky, investor A may take more than his share of the pie at the expense of investor B. And yes, all investors feel richer when stocks soar. But an owner can exit only by having someone take his place. If one investor sells high, another must buy high. For owners as a whole, there is simply no magic - no shower of money from outer space - that will enable them to extract wealth from their companies beyond that created by the companies themselves."

Buffet's main criticism was for the financial professionals who help individuals to trade, so that in aggregate investors lose part of the pie in fees to what Buffet calls "helpers". However, Keynes, Bogle and Buffet all point out the basic fact that short run returns can deviate from the returns generated by the economy and earned by firms, the investment return, but in the long run, this is all there is.

This discussion of what generates stock market returns is provided since, in the long run, the average stock market return should approximate the average investment return,${ }^{32}$ that is, the speculative return should average out to zero. ${ }^{33}$ There are two ways in which we can look at the investment return; the first is to look at average rates of return on equity actually earned by companies and the second to look at a Gordon growth model for the economy as a whole.

In Schedule 8 is the average ROE for Corporate Canada since 1980 as reported by Statistics Canada (Table \# 1800003). Over this 33-year period, the average ROE has been 9.52 per cent. The third column reports the annual return on the TSX Composite, which over the same period, has been 10.36 per cent or 0.86 per cent more, which is approximately the median ROE. However, the rough equality over 26 years hides the significant year-to-year variation, where speculative returns have been significantly higher or lower. For example, in 1986, Corporate Canada earned 9.49 per cent but the TSX Composite only earned 8.95 per cent, so there was a short-term speculative loss of 0.54 per cent. It wasn't until 1989 when the TSX returned 21.37 per cent, compared to Corporate Canada's ROE of 11.79 per cent, that the speculative return turned positive. Also note that the speculative return is highly volatile with a standard deviation of 16.0 per cent, i.e., is more than five times more volatile than the investment return earned by companies.

The second way of looking at the investment return is that used by Jack Bogle, the founder of Vanguard Mutual funds. He estimated the investment return using the Gordon growth model, where at the start of each year, he added the subsequent five year earnings growth to the dividend yield assuming that expectations were, on average, realised. He then took this analysis back to 1900 and provided the exhibit in Schedule 9. Bogel's estimates marginally understate the investment return since he should have used the forecast dividend yield, but as he noted it did not materially affect the results. He estimated the investment return at 8.8 per cent or slightly less than the average U.S. stock market return of 9.1 per cent.

\footnotetext{
31 Warren Buffet's comments in Berkshire Hathaway's 2006 Annual Report as reported in Fortune, March $20,2006$.

32 It is an approximation since it depends on the market to book ratio at the start of the period.

33 This partly depends on the starting date of the data.
} 
However, since he underestimated the investment return, the difference in reality is de minimus. Just like Keynes, Bogle also noted the persistent tendency for reversion towards the mean, which is another way of saying that high or low stock markets and PE multiples do not last. As Bogle noted (page 11):

"Over the long run it is the durable economics of enterprise - enterprise - that has determined total return: the evanescent emotions of investing - speculation -so important over the short run, has ultimately proven to be meaningless."

The approach of Keynes, Buffet and Bogle is a standard approach used by fundamental investors who look at individual stocks, rather than trying to time the market.

If Keynes, Buffet and Bogel are correct, as in the long run they have to be, we might ask why is the stock market discount rate currently is so low (if Fernandez et al's survey results are true) compared to historic corporate profitability? One reason could be lowered corporate profitability. We can assess this by looking at corporate profitability as recorded in the GDP accounts. This data has a significant advantage over GAAP-based corporate results for two main reasons: first it ignores capital gains since in aggregate these are not income, and second it is based on tax return data, where the incentive is to under- instead of over-report income.

Schedule 10 offers Canadian after-tax net income and dividends paid to both residents and non-residents as a percentage of GDP. We can clearly see the business cycle, with the drops in after-tax net income in the early 1970's and 1980's, the extended adjustment to free trade effects in the mid-1990's and the recent impact of the 2008/9 financial crisis. However, there is no sign of any serious change in the proportion of Canadian GDP going to profits, although we can see the recent impact of high commodity prices. Similarly, there is no change in the proportion of GDP being paid out as dividend income. What is clear from Schedules 8 and 10 is that the profitability of Corporate Canada has not significantly changed. If nothing in the "real economy" seems to have changed, it indicates that it is a financial market change.

\section{SECTION VII DISCOUNTED CASH FLOW MODELS OF THE DISCOUNT RATE}

In Schedule 11 is a graph that comes from a survey of 392 U.S. Chief Financial officers by Graham and Harvey. The most common way of estimating the discount rate for a firm is to use the capital asset pricing model (CAPM) which is as follows:

$$
K=R_{F}+M R P^{*} \beta
$$

The time value of money is reflected in the risk-free rate and the risk value of money in the risk premium, which is the product of the market risk premium (MRP) and the individual firm's beta ( $\beta$ ) coefficient. Research tells us that 70 per cent of U.S. CFOs use the CAPM and a further 30 per cent use a multi-beta approach such as the Fama-French (1993) three-factor model. Multi-beta models, while slightly more general than the CAPM, do not alter the average rate of return, which is anchored by the risk-free rate and market risk premium; all they do is generate slightly different estimates for individual firms. ${ }^{34}$

\footnotetext{
34 Testing which risk premium model works "best" is a nightmare as Levy and Roll (2010) have reminded us that even very small changes in realised from expected values cause insurmountable problems and making very small changes in these realised values can make the market portfolio mean variance efficient.
} 
For the market as a whole, we can simply drop the beta, which removes a major source of estimation error. The risk-free rate is then directly observable as the long Canada bond yield, while the market risk premium is reasonably objective, particularly now that we have Fernandez' survey data from thousands of professionals in the area. Hence the big advantage of risk premium models is that "normally" it is difficult to make big mistakes. In particular, they avoid one of the big problems with DCF estimates in that the forecast inflation rate is automatically incorporated in the long Canada bond yield, since we use the nominal rather than the real yield.

The CAPM is a normative model, which tells us what investors should do, not what they actually do. An alternative is to imply the discount rate that equates the market value to the stream of expected cash flows. In this way, we automatically incorporate what investors actually do in the prices they pay. The most common model is the Gordon constant growth model or

$$
\mathrm{K}=\frac{d_{1}}{P_{0}}+g
$$

which is often called the DCF model. Here we simply need the dividend yield plus the long run growth rate, since it is the long run growth rate in earnings and dividends that drives long run capital gains as Buffet, Bogel and Keyne's point out. Moreover, as Schedule 10 shows, profits and dividends are remarkably stable as a percentage of GDP. So for the market as a whole, we can use the dividend yield on the Canadian stock market and the nominal GDP growth rate as proxies for the Gordon model's estimate of the equity discount rate for the market as a whole.

Since both the DCF model and risk premium models should give the same answer, we can set them equal, which indicates that for the market as a whole

$$
\text { Riskpremium }-D C F=R_{F}-d_{1} /_{P}=g-M R P
$$

The directly observable spread between the long Canada bond yield and the TSX dividend yield is equal to the long run dividend growth rate minus the market risk premium. It is then possible to come up with a simple or naïve estimate of the market return by assuming that for the DCF model, the forecast growth rate is the actual CPI inflation rate at the time, based on year-over-year changes, plus a 3.50 per cent real growth rate. Meanwhile, for the risk premium model, we can add a long run market risk premium of 3.5 per cent to the long Canada yield. For the entire period 1956-December 2013 the average naïve DCF estimate is 10.67 per cent, while the average naïve risk premium estimate is 10.66 per cent, or a trivial difference of 0.01 per cent between the two. So "on average", these assumptions seem to make sense.

To see how robust this simple procedure is, Schedule 12 graphs the difference between the two estimates for every month since 1956 . The graph indicates that the difference was very large from the mid 1970's until the late 1990's. The reason for this difference is twofold. First, in the 1970s, inflation was increasing and bond yields did not reflect this as investors simply did not believe that the Bank of Canada and the Government would allow these high levels of inflation to continue. This resulted in very low real yields on long Canada bonds. As a result, whereas the DCF estimate directly captured the yearover-year inflation rate, the long Canada bond yield did not, leading to higher DCF than risk premium estimates.

Once investors caught up to the impact of high inflation, the reverse set in, as budget deficits at the Federal level convinced the market that the government would inflate its way out of its deficit problems, rather than bring down inflation. As a result, while the year-over-year inflation rate dropped dramatically, causing DCF estimates to fall precipitously, long Canada bond yields did not at first decline 
enough, leading to very high real yields and risk premium estimates that exceeded the DCF equivalents. It is largely this phenomenon of low real bond yields in the 1970s and 1980s and high real bond yields in the 1990s that is the major reason for the positive deviations from 1970-1982, and the negative deviations afterwards.

The second reason is simply that the real GDP growth rate and the market risk premium have not remained constant since 1956. In particular, short run growth is always higher in recessions due to the margin growth we see coming out of the recession and vice versa. Similarly, the inverse relationship between the market risk premium and the level of long Canada bond yields is not captured in these naïve models. ${ }^{35}$ However, this procedure "ballparks" the general range for both the DCF and risk premium estimates. Further, note from the graph that the difference between the DCF and risk premium estimate of the market return has gradually gone from negative to positive over the last 15 years, as long Canada bond yields have gone down and we have returned to a period of very low real yields.

The above analysis suggests that risk premium models using historic risk premiums over current long term government bond yields currently are too low and what we need is a more robust contingent risk premium model.

\section{SECTION VIII CONTINGENT RISK PREMIUM MODELS}

Contingent risk premium models, like the CCAPM, simply make the estimated discount rate contingent on the state of financial markets. ${ }^{36}$ Various indicators have been suggested, such as the aggregate dividend yield, the Price Earnings (PE) ratio, etc., but the most common one is the default spread on corporate bonds. Since corporate bonds have the possibility of default, the spread between their promised yields and the guaranteed yields on Government of Canada debt of the same maturity indicates a time-varying risk premium.

In Schedule 13 is a graph of the corporate default spreads of AA, A and BB rated bonds over equivalent maturity Government of Canada bonds. ${ }^{37}$ These yield spreads usually behave in a predictable manner. In a recession, as the risk of bankruptcy increases, investors sell off default-risky corporate debt and their liquidity drops. As a result, their bond prices fall and their yields increase relative to the long Canada bond yield causing a wider spread. Conversely, as the economy recovers and this risk recedes, the spread narrows. We can see this clearly in the high spreads during the long recession of the early 1990s, the panic of the Asian crisis and the bursting of the Internet Bubble and in particular the financial crisis of 2008-9. Note also that usually the spread increases most for BBB bonds which are the riskiest. The exception to this general rule was during the last financial crisis when the spreads for even A and AA bonds widened dramatically as liquidity in the market dried up as many banks ceased making a market in corporate bonds, except on an agency basis, and were themselves subjected to greater default risk. ${ }^{38}$ Clearly there is information in these corporate spreads about the market risk premium which makes them a candidate for use in a contingent risk premium model.

\footnotetext{
${ }^{35}$ Note in the 1990s when the Government of Canada was under serious financial pressures long Canada bonds behaved much like low risk equities as there was a very high bond beta. As a result, the market risk premium was very low, which is the opposite of today.

${ }^{36}$ See Jagganathan (1996) for an early study

${ }^{37}$ These are originally from Scotia Capital's Handbook of Debt Market Indices.

${ }^{38}$ Agency trades do not require capital, whereas normally banks hold an inventory and trade out of inventory for clients.
} 
However, a major problem is that the corporate spread reflects several factors: the probability of default; the expected recovery rate in default; the risk premium and the liquidity of the bond. Only the risk premium could then directly affect the equity rate of return since, unlike bonds, liquidity in the equity market generally increases during a financial crisis when risk premiums are likely to increase. Recent research at the Bank of Canada has helped to disentangle the liquidity from the pure default risk components in the corporate spread. Garcia and Yang ${ }^{39}$ looked at Canadian U.S. $\$$ issuers in the U.S. market, where credit default swaps were traded. They were forced to look in the U.S. market, as no data are available within Canada. However, for these Canadian, investment grade, U.S.\$ issuers, investors could purchase credit default swaps to insure against default. Further, since the liquidity risk is minimal in credit default swaps, by comparing these spreads with conventional yield spreads, they were able to disentangle the two components. Schedule 14 provides their key result.

The average (mean) overall spread increased from under 2 per cent (200 basis points, bps) in 2007 to 7 per cent at the peak of the crisis. However, the vast bulk of this increase was due to liquidity effects, where the spread increased from 1 per cent to over 4 per cent. In contrast, the pure default risk component increased from under 1 per cent $(100 \mathrm{bps})$ to about 2.5 per cent. Garcia and Yang conclude (page 29)

"our results show that for investment grade firms, the majority of the spread corresponds to liquidity: on average, the liquidity component accounts for 63 per cent of the spread."

Garcia and Yang go on to say that for non-investment grade bonds, the result is reversed, that is, the pure default risk dominates rather than the liquidity risk. Although it remains very difficult to disentangle the liquidity from the pure default risk components in corporate spreads, the Garcia and Yang results suggests that during crises, risk premiums do increase and they increase the most for the riskiest securities. However, their results also confirm that not all of a spread change is related to a change in the equity risk premium.

In 2009, the Ontario Energy Board included 50 per cent of the change in the corporate spread into its ROE adjustment model; a practise later followed by both the Regie de L'Energie du Quebec, the Board of Commissioners of Newfoundland and Labrador and, most recently, the BC Utilities Commission. ${ }^{40}$ However, the latter three have all either suspended this adjustment or made it conditional on the level of interest rates. The main reason is that the range in A-rated spreads is normally only about 2.0 per cent, so the adjustment to the discount rate is only about 1.0 per cent, which is not sufficient to adjust to the current market conditions of very low real interest rates.

The problem is that the U.S. has been very slow to recover from its deep recession and the Euro zone has barely started the process. In both cases, fiscal policy has been counter-productive in increasing taxes and cutting government spending in a recession, thereby worsening the recession. Currently, fiscal drag in the U.S., for example, is costing the U.S. about 1.75 per cent in economic growth. ${ }^{41}$ Faced with the absence of credible fiscal policy, the heavy lifting has been left to monetary policy. On September 21, 2011, the U.S. Federal Reserve announced a new program dubbed "Operation Twist." The objective of "Operation Twist" was simply to spend $\$ 400$ billion a year buying U.S. government long-term bonds to drive long-term interest rates down and help U.S. mortgage refinancing, and thus, kick-start the U.S. housing market.

\footnotetext{
39 A. Garcia and J. Yang (2009).

${ }^{40}$ I recommended the adjustment to the latter three regulators.

${ }^{41}$ Federal Reserve Board member William Dudley's estimate of the impact of the budget cuts that went into effect January 2013, quoted in Bloomberg March 6, 2013.
} 
Since the U.S. also pledged to keep the Federal Funds rate at 0.0-0.25 per cent, the effect was "quantitative easing" at the long end of the yield curve. On June 19, 2012 the Fed indicated it would continue Operation Twist beyond its original June 30 deadline, while on September 13, 2012, the Federal Reserve introduced a third round of quantitative easing $(\mathrm{QE})$. The announcement had three components:

- The Federal Funds rate will stay at $0.0-0.25$ per cent until summer 2015

- Operation Twist will continue indefinitely at about $\$ 40$ billion a month

- A new QE 3 will involve an additional \$45 billion a month in purchases of mortgage backed securities

The result was that U.S. long-term interest rates collapsed in the face of this huge monthly bond buying program reaching a low of 2.55 per cent in April 2013. In May 2013, Governor Bernanke indicated a road map for U.S. monetary policy and the bond buying program had successively reduced and longterm U.S. interest rates had bounced back somewhat. However, interest rates have not been determined by investors trading off risk and return, instead they have been determined by what RBC has called the "global policy-maker."

To see how this has affected Canada, we can look at other spreads. In particular, preferred shares have many of the characteristics of bonds except that the dividends are tax preferred; for ordinary investors they receive a dividend tax credit whereas for taxable corporates the dividend income flows through tax-free. Unlike Canadian bonds, they are unattractive to foreign purchasers who do not benefit from this tax treatment. In Schedule 15 is the spread between the A bond yield and the yield on the TSX index of conventional preferreds. What is interesting is that the spread hovered around zero until the U.S. embarked on quantitative easing in a serious way in September 2011. After that date, while bond yields followed the impact of QE downwards, preferred yields did not decrease to the same extent causing the spread to widen.

While RBC commented on the impact of the global policy-maker, it did not estimate its impact. I would regard the preferred share market as being a quintessentially Canadian market. Although it is affected by demand shifted from the bond market in the search for yield, it is not affected by QE to the same degree. From Schedule 15, I have estimated the impact of QE in the Canadian long-term (30-year) bond market to be as high as 0.80 per cent. Even with the tapering now in progress in the U.S. with rising long term interest rates, there is still about a 0.40 per cent impact. This is to say that long term Canadian interest rates during the period of $\mathrm{QE}$ have been yielding about $0.40-0.80 \%$ below where they would have been without the actions of the U.S. Federal Reserve. ${ }^{42}$

\section{CONCLUSIONS}

There is a wealth of data on rates of return. In fact, estimating the market risk premium seems to have become a cottage industry. The historic data in the U.S. and Canada is consistent with a market risk premium of 5.0-6.0 per cent using annual AM returns. Indeed, Credit Suisse's latest yearbook that documents the market risk premium for 23 countries estimates Canada's GM market risk premium using

\footnotetext{
${ }^{42}$ Note that Japan has now embarked in its own QE, while the European central bank is engaged in a complicated bluffing game of promising, but not quite delivering.
} 
data from 1900-2013 at 3.60 per cent, consistent with my own estimates from 1924 of 3.68 per cent. ${ }^{43}$ However, how this is applied to estimate a current discount rate is based on assumptions about what is constant. That is, whether the nominal or real rate of return, or the market risk premium, is a random walk and thus, the historic average is useful as a forward estimate of the expected return on the market.

In Schedule 16 is the Canadian long-term bond yield and CPI inflation rate going back to 1924 along with the 91-day Treasury Bill yield back to $1936 .{ }^{44}$ What is immediately obvious is that assuming bond yields are a random walk cannot be correct, therefore, bond returns are also not a random walk. From 1924 until the changes made by the Bank of Canada in 1953, interest rates were not responsive to inflation rates. After these changes, we began to see interest rates respond to the rising inflation rate and after 1981, the falling inflation rate. So the Fisher effect, that says that investors try and protect themselves from expected inflation, worked vaguely after these reforms, but only vaguely as the real rates of return were certainly a lot higher in the 1990s than they were in the 1970's.

I would conclude from this that there is tremendous value in the historic statistics, since they bound any estimate. However, the key player in financial markets is the central bank, and yet, normative risk premium models do not allow a central bank. Instead, the risk-return tradeoff is assumed to be the action of individual investors. Over very long time periods, I can accept that the market price of risk reflects this risk aversion and rational decision making. Conventionally, we do not use short-term interest rates to determine the discount rate, since these are determined by central bank monetary policy and do not reflect this tradeoff or long run expectations. Since the advent of quantitative easing, long-term interest rates no longer reflect this tradeoff between risk and return either. Moreover, they cannot when the U.S. Federal Reserve has been buying a trillion dollars of long-term bonds a year with the specific objective of lowering long-term interest rates. The upshot is that any estimate of the discount rate, or long run equity market return, has to be contingent on current monetary policy that has distorted this market trade-off between risk and return.

I conclude the following:

a) The normal market risk premium is 5.0-6.0 per cent based on annual rates of return and about 1.0 per cent less based on long run compound rates of return. This is based on historic evidence and expectational data.

b) There is value to making the market risk premium contingent on the state of the economy and the easiest way of doing this is by taking 50 per cent of the deviation of the A-rated credit spread from its long run, or normal value, of about 0.95 per cent. This adds about 0.35 per cent at the moment.

c) Currently, the actions of the Federal Reserve in quantitative easing, or twisting the shape of the yield curve (Operation Twist), has lowered Canadian interest rates by about 0.80 per cent below what they would have been without it. Even with the recent uptick in interest rates, this is still about a 0.40 per cent adjustment.

I have been recommending that a base long-term interest rate to be used in risk premium models is 4.0 per cent, based on the above analysis and forecast long Canada rates. This analysis produces an overall expected market return of 9.0-10.0 per cent, once we add a conventional market risk premium. This rate

\footnotetext{
43 Credit Suisse, 2014 Yearbook. I am unsure where they get the data for Canadian equity returns from 1900-1924 as am not aware of any publicly available data that go that far back. Interest rate data is also dubious, but since Canada, like the U.S and UK, was on the gold standard this data is less suspect.

44 As always these are spliced series, interest rates prior to 1936 come from the Queen's Historical Canadian Macroeconomic dataset, 1871-1994.
} 
of return is an AM return based on one year holding periods and a compound return would be about 1.70 per cent less or 7.30 per cent to 8.30 per cent. With the Bank of Canada's 2.0 per cent inflation target, this means a long run real rate of return on Canadian equities of 5.30-6.30 per cent. For a conventional 60:40 pension fund, this suggests a real rate of return of about 4.20 per cent, which is very similar to conventional actuarial assumptions for going concern valuations. ${ }^{45}$

In my judgment, allowed returns to utilities are too high and using current bond yields in the solvency valuations of pension plans and life insurers introduces problems that don't really exist. This is particularly true once we recognize that we are applying the yield on a highly liquid government benchmark bond to value illiquid insurance and pension liabilities. The author would love to take the current lump sum value of his pension, determined using prescribed rates, and invest it in a standard 60:40 balanced fund. ${ }^{46}$

\footnotetext{
${ }^{45}$ I assume a minimum 4.0 per cent long run Canadian bond return and 5.0 per cent for corporate bonds or 4.5 per cent nominal and 2.5 per cent real. FSCO puts the going concern long run average rate of return for most DB plans at 3.5-4.0\%.

${ }^{46}$ Note when DB plans have been terminated in the U.S. there is no evidence that the lump sum values have been invested $100 \%$ in inflation linked fixed income securities which is the implicit assumption involved in using these rates in valuing them.
} 


\section{REFERENCES}

L. Booth, "Estimating the Equity Risk Premium and Equity Costs: New Ways of Looking at Old Data", Journal of Applied Corporate Finance, Spring 1999.

L. Booth, "The Dividend Tax Credit and Canadian Ownership Objectives" Canadian Journal of Economics, May 1987.

R. Cohn and J. Pringle, "Imperfections in International Financial Markets: Implications for Risk and the Cost of Capital to Firms," Journal of Finance, March 1973.

Credit Suisse, Global Investment Returns Yearbook 2014, February 2014.

E. Fama and K. French, "The Cross Section of Expected Stock Returns," Journal of Finance, 47, 1993.

P. Fernandez, J. Aguirreamalloa and P. Linares, "Market risk premium and Risk free Rate used for 51 countries in 2013: a survey with 6,237 answers" IESE Business School, June 26, 2013.

Financial Services Commission of Ontario (FSCO), 2012 Report on the Funding of Defined Benefit Pension Plans in Ontario, August 2013.

Financial Services Commission of Ontario (FSCO), 2013 Report on the Funding of Defined Benefit Pension Plans in Ontario: Overview and Selected Findings, March 2014.

A.Garcia and J. Yang, "Understanding Corporate Bond Spreads Using Credit Default Swaps," Bank of Canada Review, Autumn 2009

J. Graham and C. Harvey, 2001, "The Theory and Practice of Corporate Finance: Evidence from the Field," Journal of Financial Economics 60, 2001.

J. Hull, Options, Futures and other Derivatives, Prentice Hall, (8th edition), 2013

R. Jagannathan "The conditional CAPM and the Cross Section of Expected Returns," Journal of Finance, March 1996

J. M Keynes, Review of Common Stocks as Long Term Investments, 1925, Edgar Lawrence Smith.

J. M. Keynes, The General Theory of Employment Interest and Money, Macmillan London, 1936

M. Levy and R. Roll, “The Market Portfolio May be Mean Variance Efficient After All,, Review of Financial Studies, 2010.

K. A. H. Urquhart and M.C. Buckley, Historical Statistics of Canada, McMillan Canada, 1971. 


\section{SCHEDULE 1}

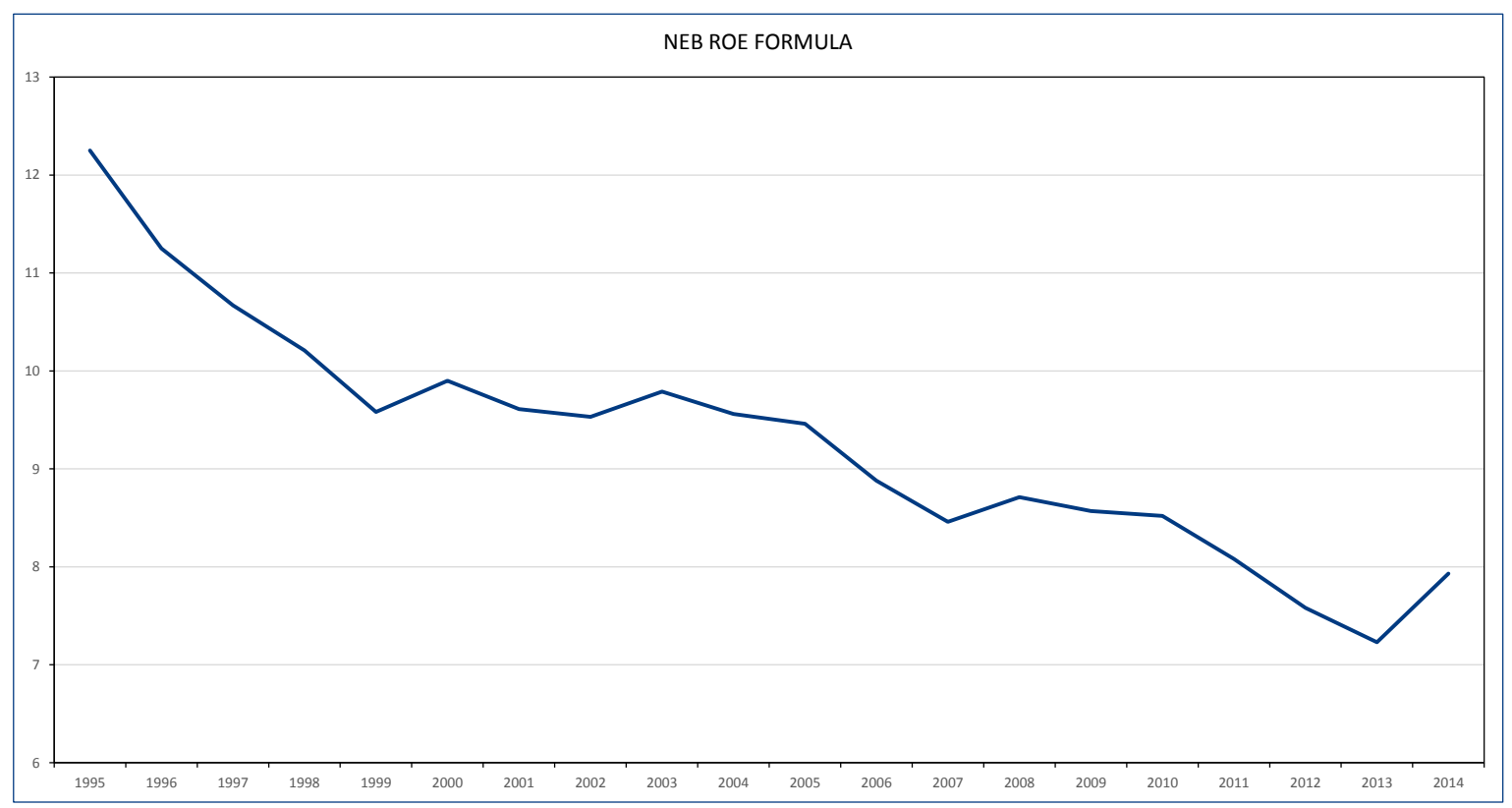

Source: as reported annually by the National Energy Board. 
SCHEDULE 2

ESTIMATED ANNUAL RETURNS

\begin{tabular}{|c|c|c|c|c|}
\hline & OLS Estimate ${ }^{1}$ & Arithmetic Mean & Geometric Mean & Standard Deviation \\
\hline \multicolumn{5}{|l|}{$1924-2013$} \\
\hline $\mathrm{CPI}$ & 3.81 & 3.00 & 2.92 & 3.97 \\
\hline Long Canadas & 5.97 & 6.43 & 6.09 & 8.82 \\
\hline Equities & 10.34 & 11.40 & 9.77 & 18.23 \\
\hline Treasury Bills & 5.82 & 4.65 & 4.57 & 4.20 \\
\hline Excess Return over Bonds & $\underline{4.37}$ & $\underline{4.97}$ & $\underline{3.68}$ & \\
\hline Excess Return over Inflation & $\underline{6.53}$ & $\underline{8.40}$ & $\underline{6.85}$ & \\
\hline
\end{tabular}

1. Ordinary least squares. 
SCHEDULE 3

CANADIAN AND U.S. RISK PREMIUM DATA 1926-2013

U.S. RISK PREMIUM ESTIMATES

\begin{tabular}{|lcccc|}
\hline \multicolumn{1}{|c}{ Overall } & OLS & AM & GM & Stdev \\
\hline Equity & 10.97 & 12.05 & 10.08 & 20.18 \\
Bonds & 5.32 & 5.81 & 5.41 & 9.45 \\
Risk Premium & 5.65 & 6.24 & 4.67 & \\
\hline
\end{tabular}

CANADIAN RISK PREMIUM ESTIMATES

\begin{tabular}{|lcccc|}
\hline \multicolumn{1}{rc}{ Overall } & OLS & AM & GM & Stdev \\
\hline Equity & 10.32 & 11.20 & 9.56 & 18.66 \\
Bonds & 6.01 & 6.43 & 6.08 & 8.92 \\
Risk Premium & 4.31 & 4.77 & 3.48 & \\
\hline
\end{tabular}


SCHEDULE 4

U.S. VS CANADA "RISK PREMIUM ESTIMATES"

\begin{tabular}{|c|c|c|c|}
\hline & Equity & Bond & Risk Premiums \\
\hline \multicolumn{4}{|c|}{ AM Returns } \\
\hline U.S. & 12.05 & 5.81 & 6.24 \\
\hline CANADA & 11.20 & 6.43 & 4.77 \\
\hline Difference & 0.84 & -0.63 & 1.47 \\
\hline \multicolumn{4}{|c|}{ GM Returns } \\
\hline U.S. & 10.08 & 5.41 & 4.67 \\
\hline CANADA & 9.56 & 6.08 & 3.48 \\
\hline Difference & 0.52 & -0.67 & 1.19 \\
\hline
\end{tabular}


SCHEDULE 5

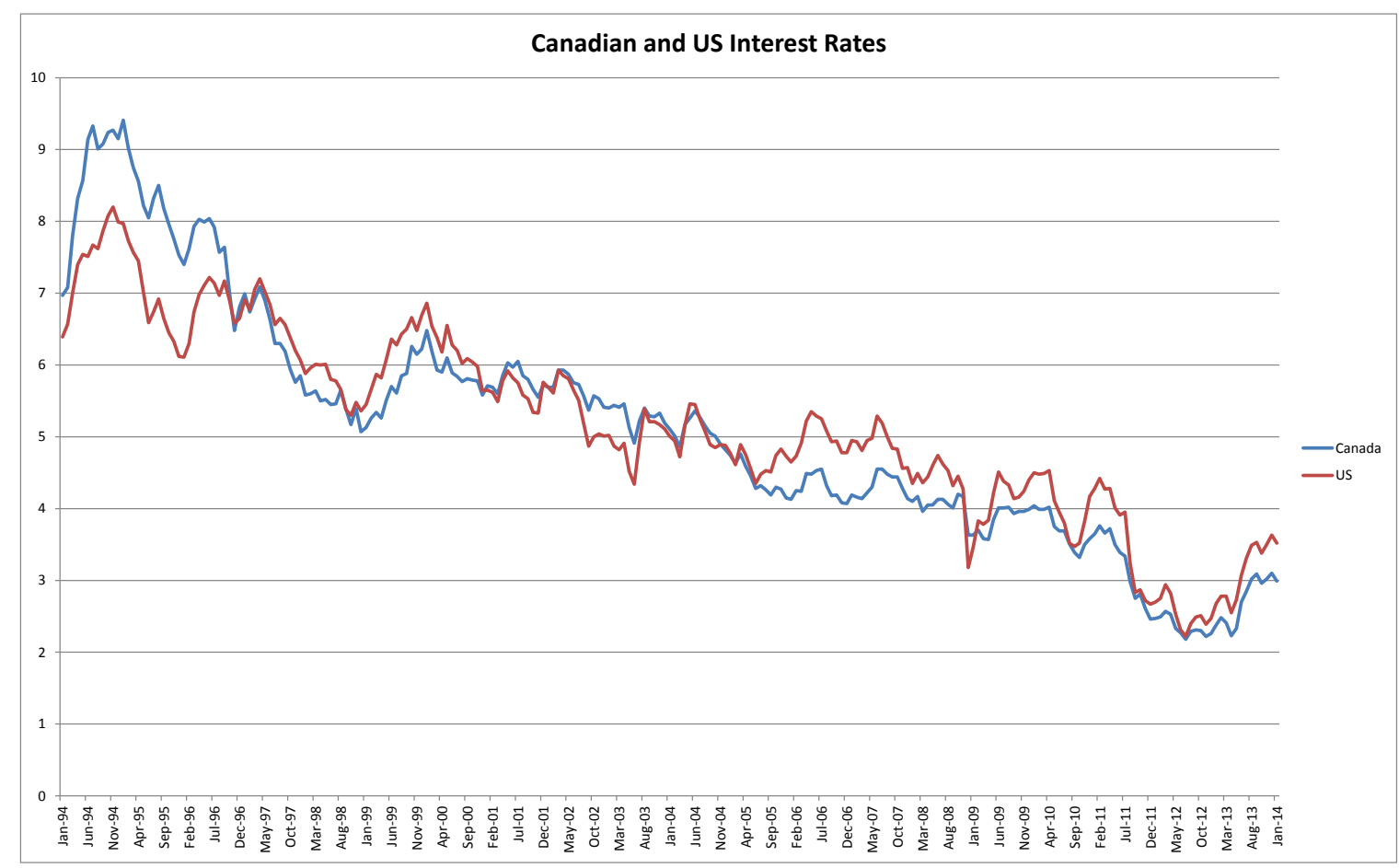


SCHEDULE 6

CURRENCY COMPOSITION OF MAJOR COUNTRY RESERVE FUND HOLDINGS

\begin{tabular}{|c|c|c|c|c|c|}
\hline (In millions of U.S. dollars) & $2012-Q 3$ & $2012-Q 4$ & 2013-Q1 & 2013-Q2 & 2013-Q3 \\
\hline Total foreign exchange holdings & $10,787,229$ & $10,952,380$ & $11,089,935$ & $11,136,041$ & $11,434,332$ \\
\hline Allocated reserves & $6,016,194$ & $6,085,143$ & $6,081,403$ & $6,074,843$ & $6,191,203$ \\
\hline Claims in US Dollars & $3,682,568$ & $3,715,026$ & $3,755,601$ & $3,751,558$ & $3,803,731$ \\
\hline Claims in Pounds sterling & 247,905 & 244,955 & 235,866 & 232,099 & 242,928 \\
\hline Claims in Japanese yen & 256,849 & 248,057 & 239,205 & 236,386 & 239,179 \\
\hline Claims in Swiss francs & 17,806 & 17,529 & 16,370 & 16,308 & 16,955 \\
\hline Claims in Canadian dollars & $\ldots$ & 91,052 & 95,873 & 109,867 & 112,521 \\
\hline Claims in Australian dollars & $\ldots$ & 89,644 & 89,083 & 101,633 & 102,294 \\
\hline Claims in Euros & $1,456,681$ & $1,477,227$ & $1,437,969$ & $1,453,924$ & $1,495,918$ \\
\hline Claims in other currencies & 354,384 & 201,653 & 201,437 & 173,068 & 177,677 \\
\hline Unallocated reserves & $4,711,035$ & $4,867,237$ & $5,008,532$ & $5,061,198$ & $5,243,128$ \\
\hline
\end{tabular}

http://www.imf.org/external/np/sta/cofer/eng/index.htm 


\section{SCHEDULE 7}

TABLE 2 MARKET RISK PREMIUM USED IN 2008 BY 884 FINANCE PROFESSORS

\begin{tabular}{|c|c|c|c|c|c|c|c|c|}
\hline & & USA & Euro & UK & Canada & Australia & Other & Sum \\
\hline \multirow[t]{8}{*}{ MRP used in 2008} & Average & $6.3 \%$ & $5.3 \%$ & $5.5 \%$ & $5.4 \%$ & $5.9 \%$ & $7.9 \%$ & \\
\hline & St. dev. & $2.2 \%$ & $1.5 \%$ & $1.9 \%$ & $1.3 \%$ & $1.4 \%$ & $3.9 \%$ & \\
\hline & MAX & $19.0 \%$ & $10.0 \%$ & $10.0 \%$ & $8.0 \%$ & $7.5 \%$ & $27.0 \%$ & \\
\hline & Q3 & $7.2 \%$ & $6.0 \%$ & $7.0 \%$ & $6.0 \%$ & $7.0 \%$ & $10.0 \%$ & \\
\hline & Median & $6.0 \%$ & $5.0 \%$ & $5.0 \%$ & $5.1 \%$ & $6.0 \%$ & $7.0 \%$ & \\
\hline & Q1 & $5.0 \%$ & $4.1 \%$ & $4.0 \%$ & $5.0 \%$ & $6.0 \%$ & $5.5 \%$ & \\
\hline & $\min$ & $0.8 \%$ & $1.0 \%$ & $3.0 \%$ & $2.0 \%$ & $2.0 \%$ & $2.0 \%$ & \\
\hline & Number & 487 & 224 & 54 & 29 & 23 & 67 & 884 \\
\hline
\end{tabular}

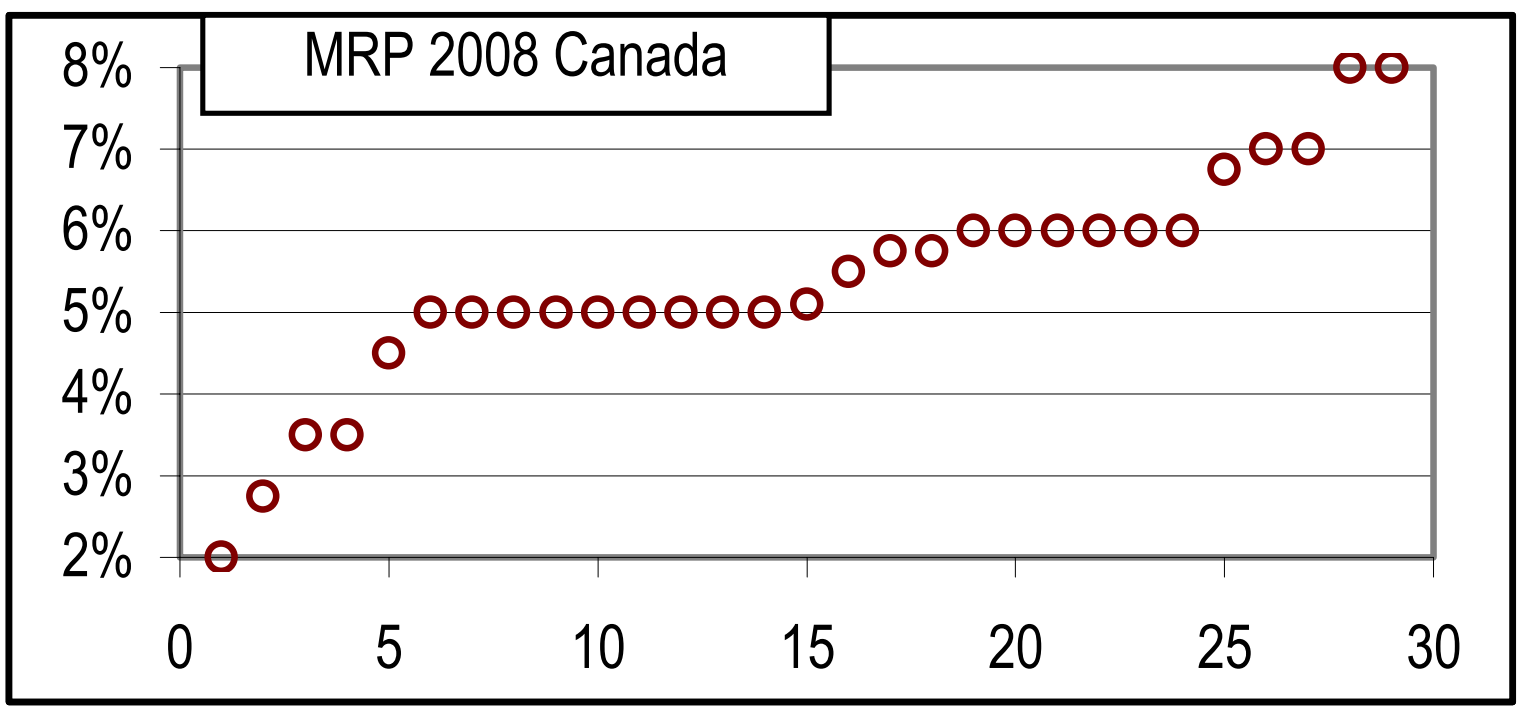




\section{SCHEDULE 8}

\begin{tabular}{|c|c|c|c|}
\hline & & & \\
\hline & ROE & TSX & Spec \\
\hline 1980 & 15.05 & 30.13 & 15.09 \\
\hline 1981 & 11.70 & -10.25 & -21.95 \\
\hline 1982 & 6.80 & 5.54 & -1.26 \\
\hline 1983 & 9.34 & 35.49 & 26.15 \\
\hline 1984 & 10.53 & -2.39 & -12.92 \\
\hline 1985 & 10.47 & 25.07 & 14.60 \\
\hline 1986 & 9.49 & 8.95 & -0.54 \\
\hline 1987 & 11.19 & 5.88 & -5.31 \\
\hline 1988 & 12.97 & 11.08 & -1.89 \\
\hline 1989 & 11.79 & 21.37 & 9.58 \\
\hline 1990 & 7.48 & -14.80 & -22.28 \\
\hline 1991 & 3.53 & 12.02 & 8.48 \\
\hline 1992 & 1.56 & -1.43 & -2.99 \\
\hline 1993 & 3.69 & 32.55 & 28.86 \\
\hline 1994 & 6.57 & -0.18 & -6.75 \\
\hline 1995 & 9.55 & 14.53 & 4.98 \\
\hline 1996 & 10.29 & 28.35 & 18.06 \\
\hline 1997 & 10.86 & 14.98 & 4.12 \\
\hline 1998 & 8.83 & -1.58 & -10.42 \\
\hline 1999 & 9.82 & 31.71 & 21.90 \\
\hline 2000 & 10.92 & 7.41 & -3.51 \\
\hline 2001 & 7.41 & -12.57 & -19.98 \\
\hline 2002 & 5.68 & -12.44 & -18.12 \\
\hline 2003 & 9.64 & 26.72 & 17.08 \\
\hline 2004 & 11.62 & 14.48 & 2.86 \\
\hline 2005 & 12.70 & 24.13 & 11.43 \\
\hline 2006 & 13.96 & 17.26 & 3.30 \\
\hline 2007 & 12.86 & 9.83 & -3.03 \\
\hline 2008 & 9.44 & -33.00 & -42.44 \\
\hline 2009 & 8.06 & 35.05 & 26.99 \\
\hline 2010 & 9.90 & 17.61 & 7.71 \\
\hline 2011 & 9.60 & -8.71 & -18.31 \\
\hline 2012 & 10.28 & 7.19 & -3.09 \\
\hline 2013 & 10.05 & 13.00 & 2.95 \\
\hline Average & 9.52 & 10.38 & 0.86 \\
\hline Volatility & 2.93 & 16.36 & 15.97 \\
\hline
\end{tabular}




\section{SCHEDULE 9}

Eleven Decades of Returns on U.S. Stocks 7 .

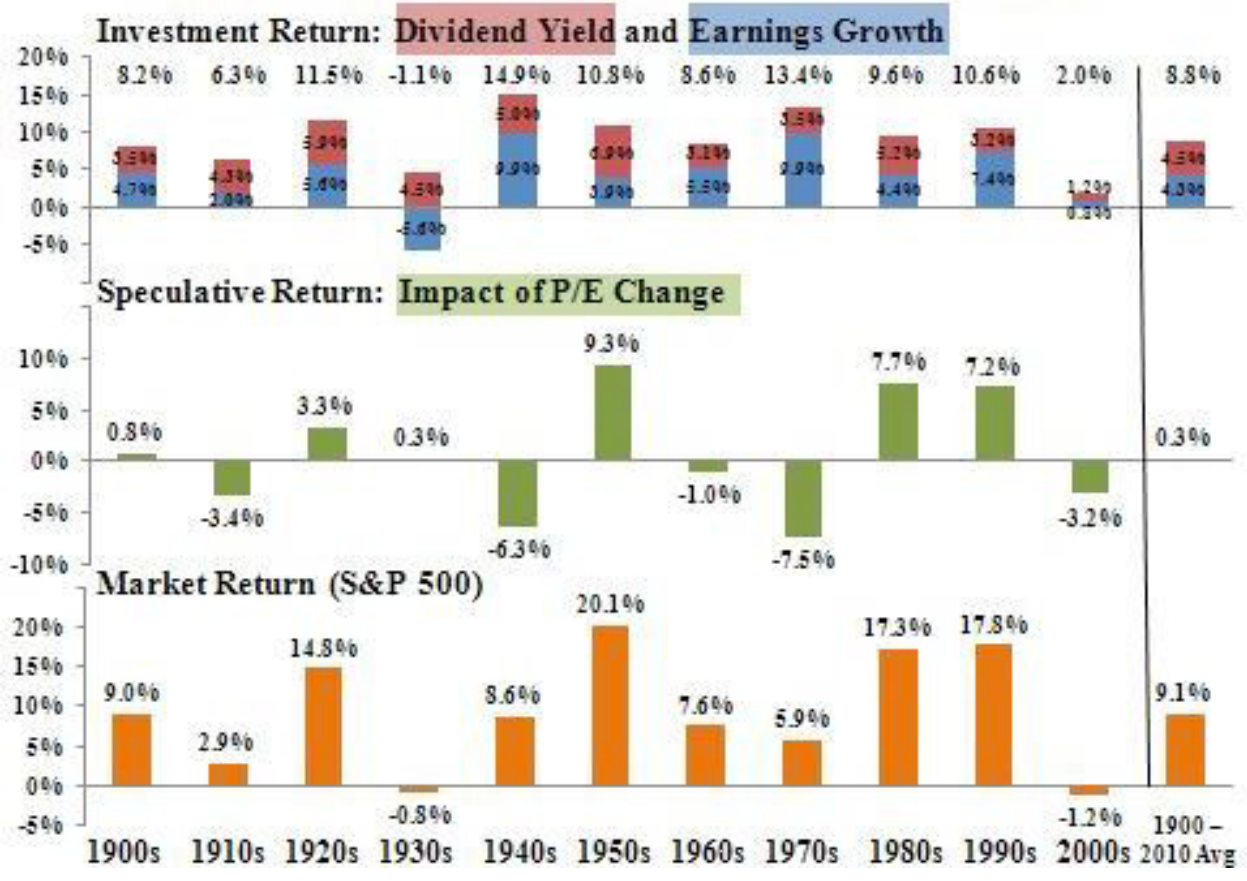


SCHEDULE 10

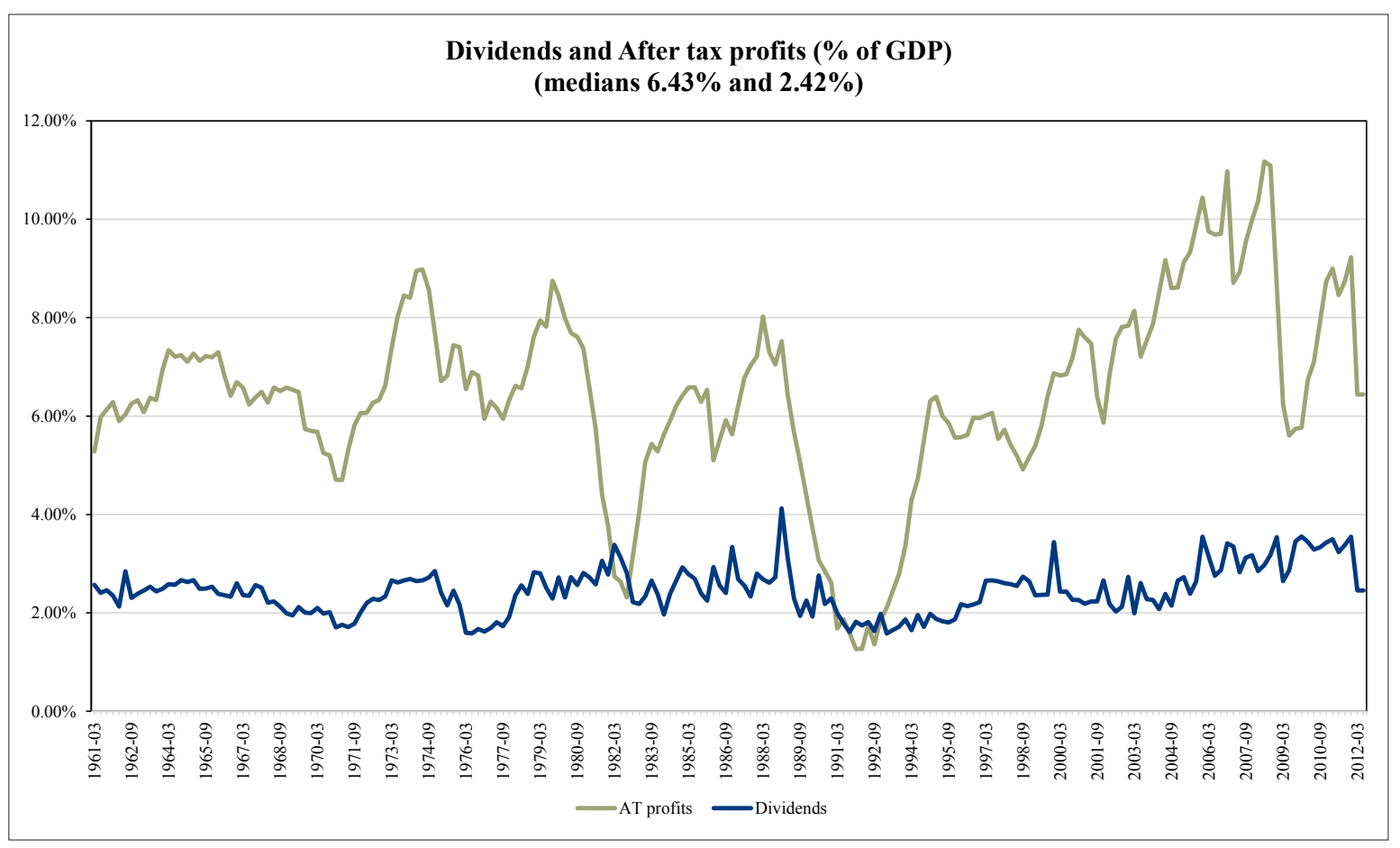




\section{SCHEDULE 11}

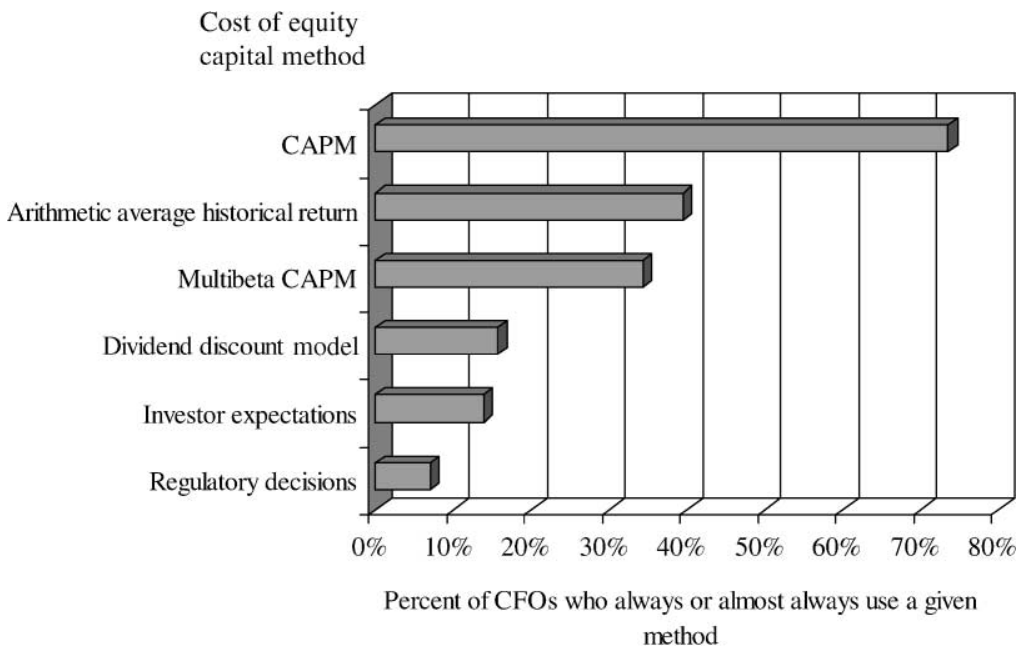




\section{SCHEDULE 12}

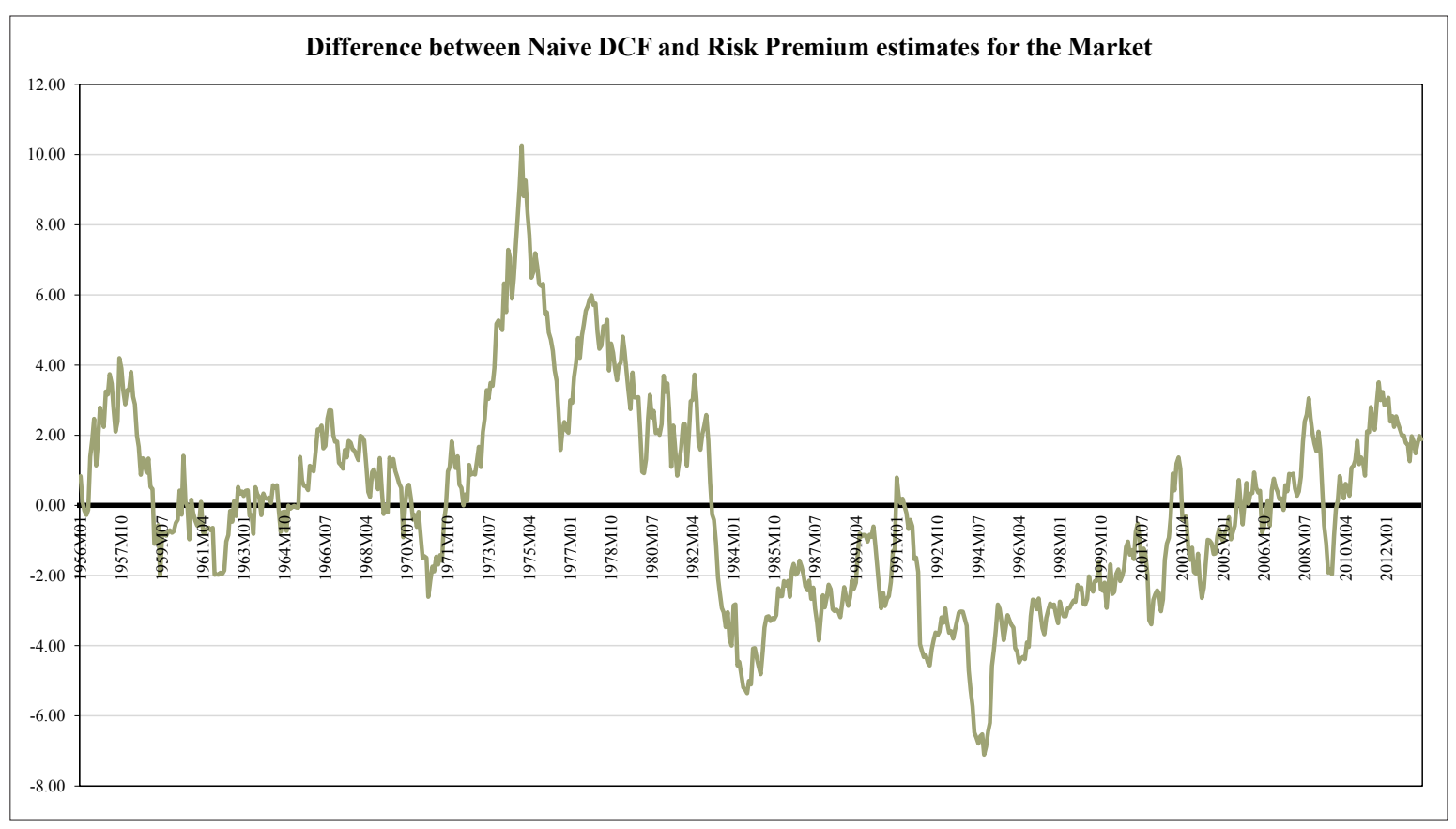


SCHEDULE 13

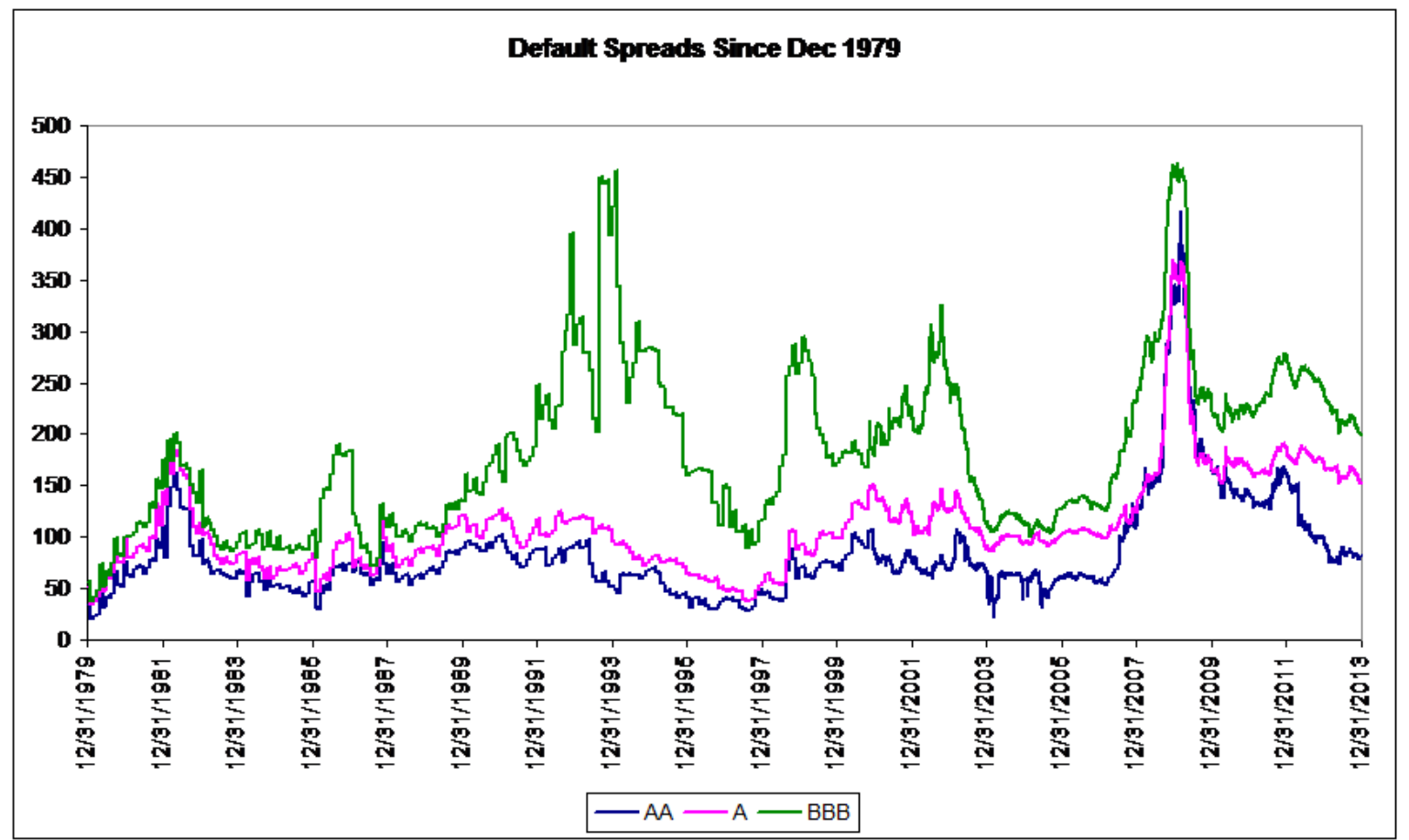




\section{Chart 2: Corporate bond spreads for an average investment-grade firm}

Synthetic zero-coupon 5-year bond

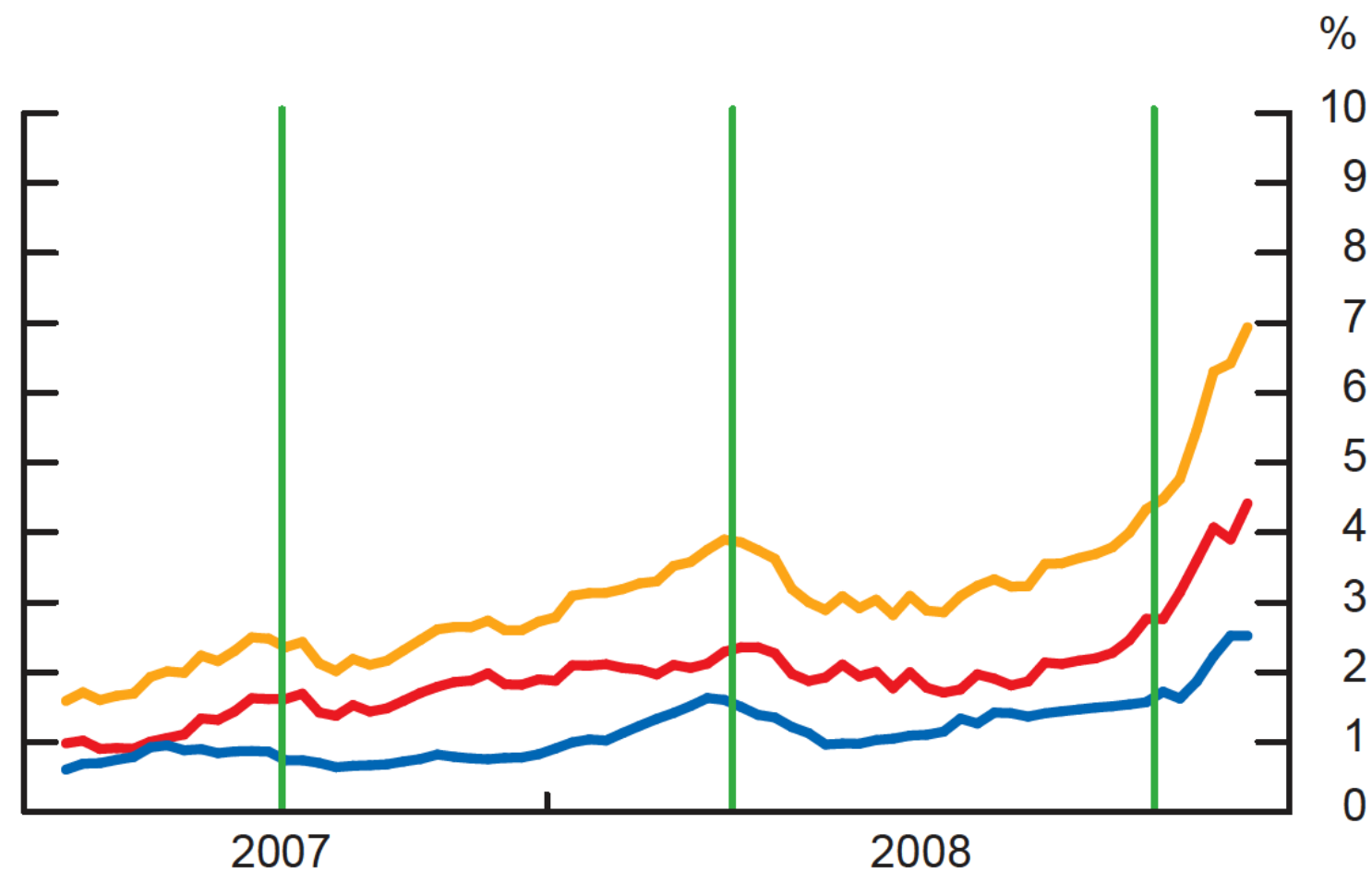

Mean liquidity $\quad$ Mean default $\quad$ Mean spread

Note: The green lines represent the dates when Bear Stearns liquidated two hedge funds that had invested in mortgagebacked securities (31 July 2007), the Federal Reserve Bank of New York announced that it would provide term financing to facilitate JP Morgan Chase's acquisition of Bear Stearns (24 March 2008), and Lehman Brothers filed for Chapter 11 bankruptcy (15 September 2008). 
SCHEDULE 15

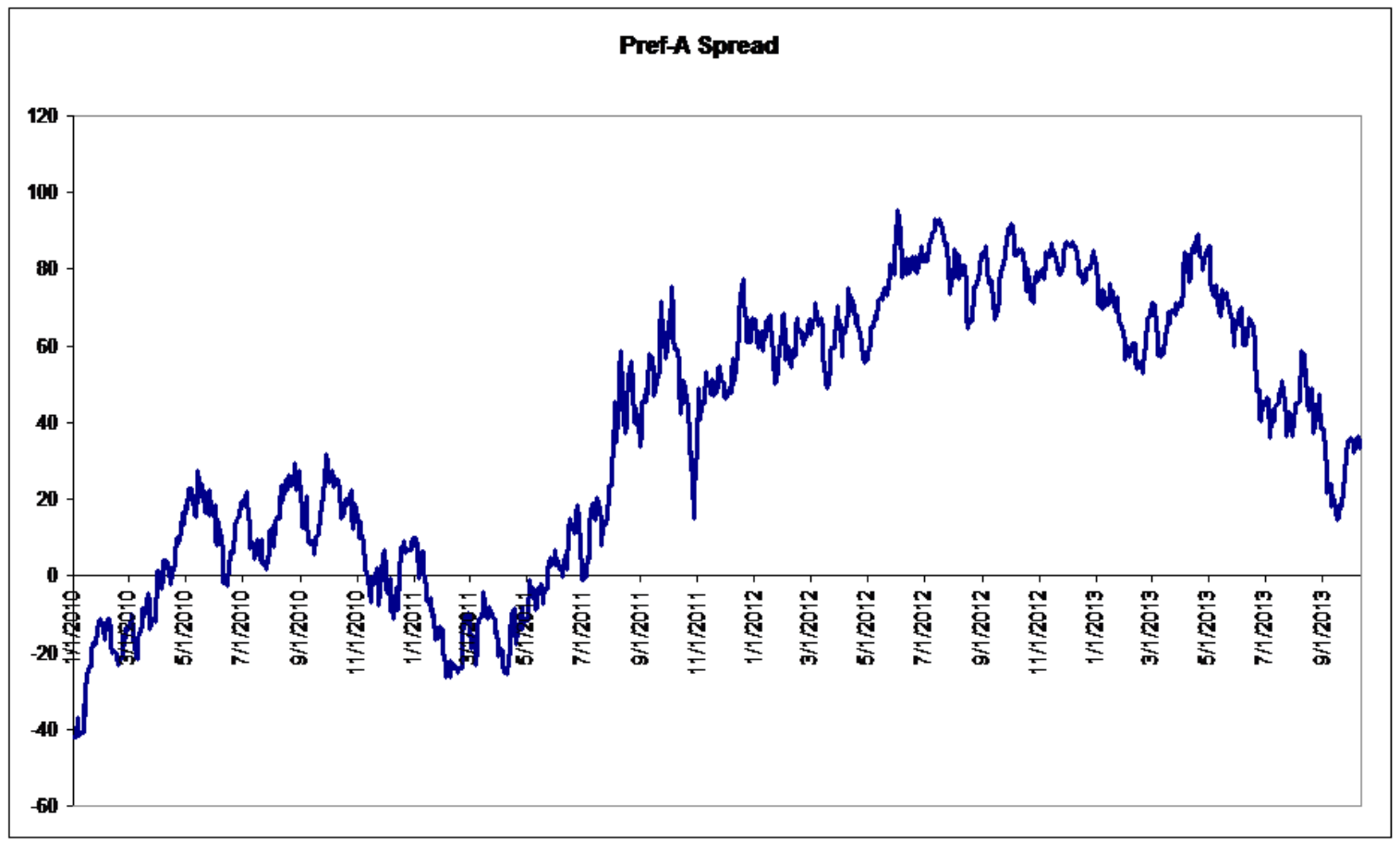


SCHEDULE 16

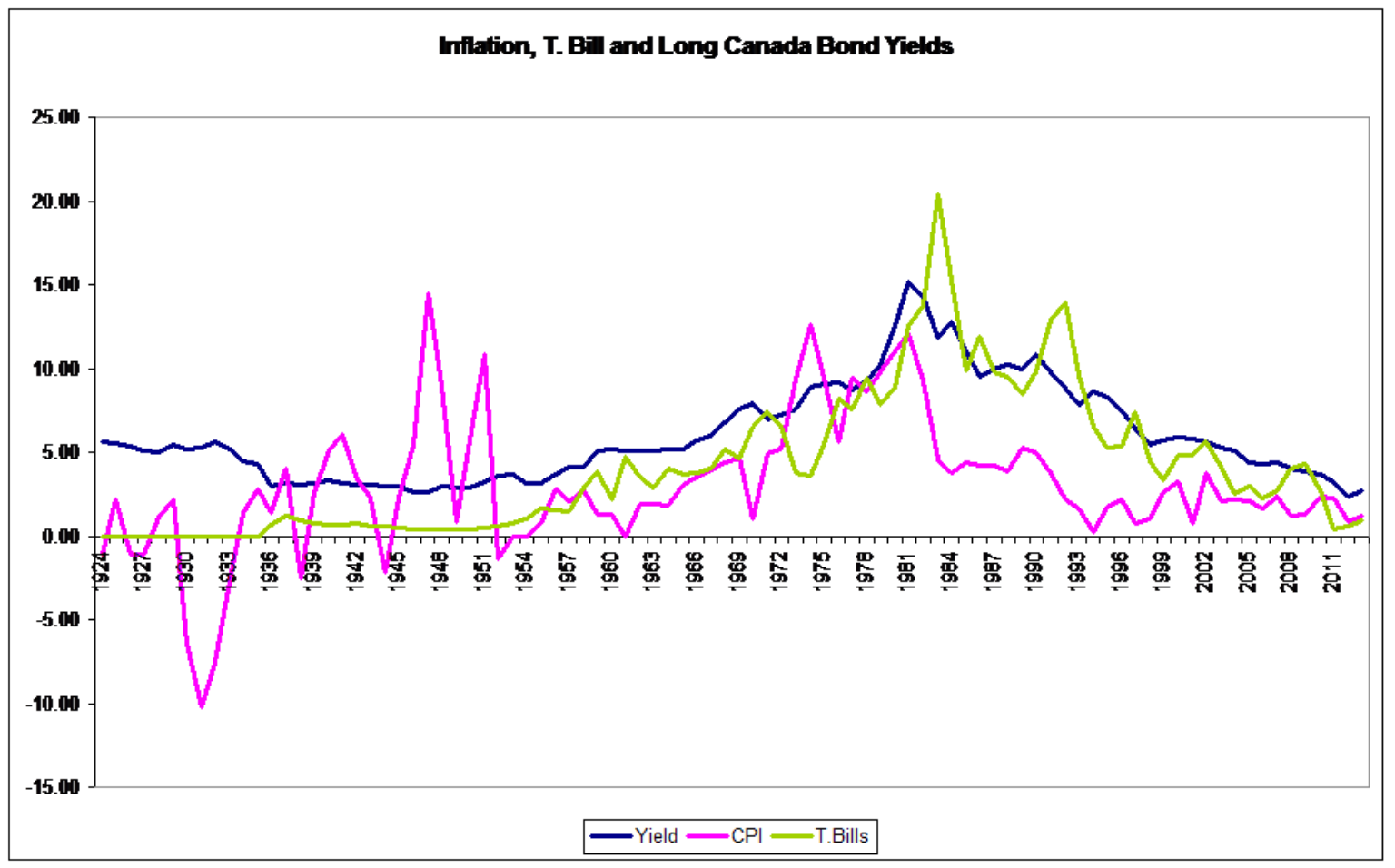




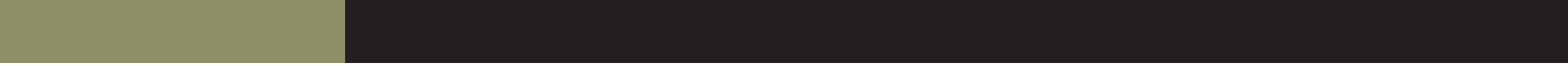




\title{
ABOUT THE SCHOOL OF PUBLIC POLICY
}

The School of Public Policy will become the flagship school of its kind in Canada by providing a practical, global and focused perspective on public policy analysis and practice in areas of energy and environmental policy, international policy and economic and social policy that is unique in Canada.

The mission of The School of Public Policy is to strengthen Canada's public service, institutions and economic performance for the betterment of our families, communities and country. We do this by:

- Building capacity in Government through the formal training of public servants in degree and non-degree programs, giving the people charged with making public policy work for Canada the hands-on expertise to represent our vital interests both here and abroad;

- Improving Public Policy Discourse outside Government through executive and strategic assessment programs, building a stronger understanding of what makes public policy work for those outside of the public sector and helps everyday Canadians make informed decisions on the politics that will shape their futures;

- Providing a Global Perspective on Public Policy Research through international collaborations, education, and community outreach programs, bringing global best practices to bear on Canadian public policy, resulting in decisions that benefit all people for the long term, not a few people for the short term.

Our research is conducted to the highest standards of scholarship and objectivity. The decision to pursue research is made by a Research Committee chaired by the Research Director and made up of Area and Program Directors. All research is subject to blind peer-review and the final decision whether or not to publish is made by an independent Director.

\author{
The School of Public Policy \\ University of Calgary, Downtown Campus \\ 906 8th Avenue S.W., 5th Floor \\ Calgary, Alberta T2P $1 \mathrm{H} 9$ \\ Phone: 4032107100
}

\section{DISTRIBUTION}

Our publications are available online at www.policyschool.ca.

\section{DISCLAIMER}

The opinions expressed in these publications are the authors' alone and therefore do not necessarily reflect the opinions of the supporters, staff, or boards of The School of Public Policy.

\section{COPYRIGHT}

Copyright ( 2014 by The School of Public Policy.

All rights reserved. No part of this publication may be reproduced in any manner whatsoever without written permission except in the case of brief passages quoted in critical articles and reviews.

\section{DATE OF ISSUE}

April 2015

\section{MEDIA INQUIRIES AND INFORMATION}

For media inquiries, please contact Morten Paulsen at 403-453-0062. Our web site, www.policyschool.ca, contains more information about The School's events, publications, and staff.

\section{DEVELOPMENT}

For information about contributing to The School of Public Policy, please contact Courtney Murphy by telephone at 403-210-7201 or by e-mail at cdmurphy@ucalgary.ca.

\section{ISSN}

1919-112x SPP Research Papers (Print)

1919-1138 SPP Research Papers (Online) 


\section{RECENT PUBLICATIONS BY THE SCHOOL OF PUBLIC POLICY}

WHAT CANADA COULD LEARN FROM U.S. DEFENCE PROCUREMENT: ISSUES, BEST PRACTICES AND RECOMMENDATIONS http://policyschool.ucalgary.ca/?q=content/what-canada-could-learn-us-defence-procurement-issues-best-practices-and-recommendations Anessa Kimball | April 2015

WHY DELAY THE INEVITABLE: WHY THE AIIB MATTERS TO CANADA'S FUTURE

http://policyschool.ucalgary.ca/?q=content/why-delay-inevitable-why-aiib-matters-canadas-future Eugene Beaulieu and Wendy Dobson | April 2015

IMPROVING THE ACQUISITION PROCESS IN CANADA

http://policyschool.ucalgary.ca/?q=content/improving-acquisition-process-canada

Craig Stone | April 2015

A PRIMER ON RECENT CANADIAN DEFENCE BUDGETING TRENDS AND IMPLICATIONS

http://policyschool.ucalgary.ca/?q=content/primer-recent-canadian-defence-budgeting-trends-and-implications Dave Perry | April 2015

PEERING INTO ALBERTA'S DARKENING FUTURE: HOW OIL PRICES IMPACT ALBERTA'S ROYALTY REVENUES

http://policyschool.ucalgary.ca/?q=content/peering-alberta\%E2\%80\%99s-darkening-future-how-oil-prices-impact-alberta\%E2\%80\%99sroyalty-revenues

Sarah Dobson | March 2015

THE SIREN SONG OF ECONOMIC DIVERSIFICATION: ALBERTA'S LEGACY OF LOSS

http://policyschool.ucalgary.ca/?q=content/siren-song-economic-diversification-albertas-legacy-loss Meredith McDonald and Ted Morton | March 2015

CAUGHT IN THE MIDDLE: SOME IN CANADA'S MIDDLE CLASS ARE DOING WELL; OTHERS HAVE GOOD REASON TO WORRY http://policyschool.ucalgary.ca/?q=content/caught-middle-some-canadas-middle-class-are-doing-well-others-have-good-reason-worry Philip Cross and Munir Sheikh | March 2015

WHO ARE THE HOMELESS? NUMBERS, TRENDS AND CHARACTERISTICS OF THOSE WITHOUT HOMES IN CALGARY

http://policyschool.ucalgary.ca/?q=content/who-are-homeless-numbers-trends-and-characteristics-those-without-homes-calgary Meaghan Bell, Nicole Jackson, Ali Jadidzadeh and Ron Kneebone | March 2015

THE EXEMPT MARKET IN CANADA: EMPIRICS, OBSERVATIONS AND RECOMMENDATIONS

http://policyschool.ucalgary.ca/?q=content/exempt-market-canada-empirics-observations-and-recommendations Vijay Jog | March 2015

\section{BETTER OFF DEAD: “VALUE ADDED” IN ECONOMIC POLICY DEBATES}

http://policyschool.ucalgary.ca/?q=content/better-dead-\%E2\%80\%9Cvalue-added\%E2\%80\%9D-economic-policy-debates Trevor Tombe | March 2015

REPORT OF THE COMMISSION FOR THE REVIEW OF SOCIAL ASSISTANCE IN ONTARIO: TAKING STOCK TWO YEARS LATER http://policyschool.ucalgary.ca/?q=content/report-commission-review-social-assistance-ontario-taking-stock-two-years-later Munir Sheikh | March 2015

MINING TAXATION IN COLOMBIA

http://policyschool.ucalgary.ca/?q=content/mining-taxation-colombia

Duanjie Chen and Guillermo Perry | February 2015 